\title{
REVISION OF THE TWO-WINGED FLIES OF THE FAMILY CLUSIIDAE.
}

\author{
By A. L. Melander and Naom George Argo, \\ Of the State College of Washington, Pullman.
}

The family Clusiidae, sometimes called the Heteroneuridae or the Clusiodidae, is generally regarded as one of the rarer groups of the Diptera. Seldom are its members met with in more than solitary individuals. In our experience in collecting a hundred thousand specimens of Diptera but a few dozen representatives of Clusiidae have been encountered.

Previously there have been described from the entire world 13 valid genera and 55 species. Aldrich's Catalogue in 1905 listed but 2 genera and 12 species as known from North America. The subsequent publications of Johnson and Malloch have added 11 recognized new species to the American list. Fifteen species have been described from Europe and the same number from South America, while four species have been recorded from the islands south of Asia. The material secured for the present study, amounting to some 400 specimens, has produced 52 species, of which 25 are new. With the extension in distribution of species originally described from Europe or South America there are now known to occur in North America, including Central America, a total of 58 species belonging to 7 genera. Thus in its present status the family includes 80 recognized species distributed among 13 genera.

The Clusiidae are restricted in their distribution to Europe, North and South America, and the East Indies. No species have been described from Africa, Australia, or Asia, but there is mention by Lefroy of the occurrence of an undetermined species in India. Judging from the material at hand, the members of this family are more abundant both in individuals and in species in Neotropical than in either the Palaearctic or Nearctic regions.

In most of the literature dealing with this group of insects the family designation "Heteroneuridae" has been used. Coquillett

No. 250I.-Proceedings U. S. National museum, Vol. 64, Art. II. 
in 1904 pointed out that while Fallen used the name Heteroneura in 1823 to designate this group, he had previously, in 1810, used the same name for a genus of the Platypezidae. Accordingly Coquillett proposed to replace Heteroneura Fallen, 1823, by the genus name Clusiodes and to call the family the Clusiodidae. In this course he has been followed by Johnson and by Malloch in their revisions of the United States forms of the family. Kertesz, Frey, and Collin, in publications subsequent to Coquillett's change, still retain Heteroneura as referring to the present group, while Hendel, Frey, 1921, and Aldrich (in litt.) prefer to base the family name on the oldest validly included genus, Clusia. As the last course appears to us the most logical, the family designation Clusiidae is used in the present paper.

The family Clusiidae includes small flies, varying in length from 2 to about 6 millimeters. Most of the species measure about 3 or 4 millimeters. They vary in color from pale yellow to black. The thorax especially is often variegated with black and yellow pattern, as sometimes also are the abdomen and legs. The wings range in color from a yellowish hyaline to a smoky brown, and from a uniform color to a variegation with as many as three or four large spots. Characteristic of many species distributed among several genera is an apical clouding, especially pronounced along the end of the second vein. Normally the wings are fully rounded and somewhat more than twice as long as wide. The distribution of the crossveins varies greatly. In some of the genera the crossveins are approximated more than in other Acalypterates, hence this character has been commonly used as a family distinction. However, in other genera the crossveins are no closer together than usual. The antennae are always yellowish, the third joint more or less orbicular, with nearly apical arista. The second joint usually bears a conspicuous dorsal bristle. The arista ranges from pubescent to densely plumose. Most of the species have the arista openly short-plumose, but here and there a species is found where the plumosity is heavily bushy.

Great variation is common among the specimens from Central America. These variations, especially in.color pattern, are very suggestive of the mutants in Drosophila which have arisen and have been perpetuated in the genetics laboratories. From their similarity it seems quite possible that they have arisen in the same way-by mutation. In warm damp climates the mutant flies have abundant opportunity to survive, and races that might die out in a more nhospitable environment continue their existence in the Tropics. This renders the problem of deciding on species limits extremely difficult if not quite impossible. Just where to draw the line between species, just how much variation to ascribe to mutation or to Men- 
delian recombination within a single species, require the services of some future experimental geneticist; but in view of the great rarity of specimens in this family the conclusions advanced in the following pages are given as a taxonomist's solution. A "splitter," disregarding the evidence produced by breeders of Drosophita, would find opportunity in many cases, especially with the tropical forms, to erect a new species for almost every individual, and still not exceed species characters accepted in other groups.

Chaetotaxy is important in identifying the different genera. At first it would appear that the genera are based too closely upon permutations of a few bristle characters, and hence are purely artificial concepts. However, the degree of development of such bristles as the fronto-orbitals, cruciate frontals, ocellars, postverticals, prothoracic, dorsocentrals, preapical tibials, and bristles on the first vein, leads to the primary separation of species into groups that may be regarded as natural genera. Williston has doubted the appropriateness of some of these chaetotactic genera, and in his North American Diptera has questioned the validity of characters like the preapical or cruciate bristles. The removal of Williston's species Heteroneura lumbalis and $H$. valida from Heteromeringia to Sobarocephala straightens out the seeming discrepancy and stabilizes all three genera.

The substance of the present review was presented by Mrs. Argo to satisfy the thesis requirement for the degree of master of science in zoology at the State College of Washington. With the inclusion of subsequent material the senior author has rewritten the paper and shares equally in the responsibility of its presentation. We express herewith due appreciation and gratitude to Dr. J. M. Aldrich for forwarding the unworked Clusiidae of the United States National Museum, to Dr. O. A. Johannsen for the loan of the Cornell material, including cotypes of some of Williston's species, and to R. C. Shannon, who had anticipated monographing this family but who kindly relinquished his aggregated material. It was Mr.Shannon's request that we carry on his project that served as the first stimulus for undertaking this review. To Maj. E. E. Austen we also record gratefulness for information regarding types in the British Museum.

The photographs for the plates were made by the senior author, using a Zeiss $1 \mathrm{C}$ Tessar lens of $12 \mathrm{~cm}$. focus, stopped to $\mathrm{f} / 25$. With a 4-foot camera the initial magnification was almost ten times. The specimens were lighted by a 400-watt stereopticon bulb, and were given a 5-minute exposure on Orthonon plate. To bring out the neuration and chaetotaxy they were given a supplementary silhouetting exposure of 20 seconds, using a substage microscope lamp placed directly behind the specimen. Even with the ortho- 
chromatic plate the customary yellows, browns, and black are not well differentiated and due allowance for color values must be made in interpreting the figures.

This paper is a contribution from the Zoological Laboratory of the State College of Washington in Pullman.

KEY TO THE GENERA OF CLUSIIDAE.

1. Costa broken beyond humeral crossvein, auxiliary vein curving forward to end considerably before termination of first vein; postverticals strong and distant; arista but little longer than antenna; eyes microscopically pubescent; cross. veins widely distant; no cruciate bristles or preapicals. Acartophthalmus Czerny.

Costa not broken near humeral crossvein, but weakened or broken near end of auxiliary vein which extends parallel with first vein even at tip; postverticals approximate, sometimes absent; arista two or more times the length of the antenna, short only in Hendelia; eyes bare .............................

2. All fronto-orbitals reclinate; prothoracic bristle vestigial or absent; cruciate bristles present on middle of front............................... 3

Foremost pair of fronto-orbital bristles convergent or proclinate.............

3. Cruciate bristles arising from the orbits; three or four fronto-orbitals of equal length; preapicals present..................................

Cruciate bristles arising from middle frontal stripe....................

4. Crossveins approximate, sections of fourth vein 1:4; preapicals present; presutural

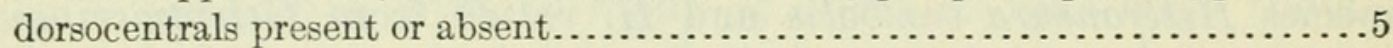

Crossveins distant, sections of fourth vein 1:3; no preapicals, postverticals, or presutural dorsocentrals.............................. Allometopon Kertesz.

5. Antennae distant, arista thick; postverticals absent; lunule covered; two fronto-

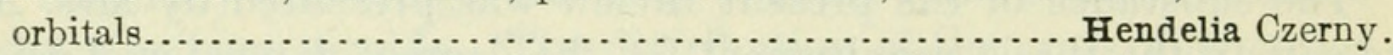

Antennae close together, arista thin; postverticals usually present; lunule exposed; two or three fronto-orbitals......................... Clusiodes Coquillett.

6. Cruciate bristles present on middle frontal stripe; crossveins distant, the sections

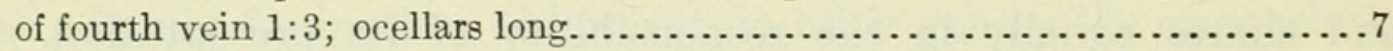

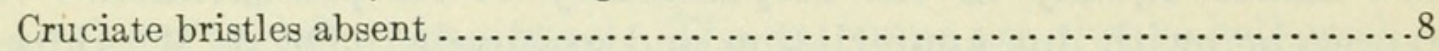

7. Postverticals absent; no prescutellar setae; prothoracic bristle strong.

Postverticals small; prescutellars present; prothoracic bristle short.

Clusia Haliday.

Paraclusia Czerny.

8. Postverticals absent; first vein bristly; ocellars small; crossveins approximate. Chaetoclusia Coquillett.

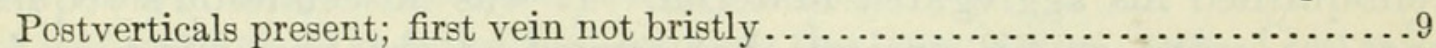

9. Preapical bristles present on middle tibiae; crossveins usually distant, the anterior crossvein nearer middle of discal cell, the last two sections of fourth vein usually



Preapical and prescutellar bristles absent; crossveins approximate, the sections of the fourth vein about $2: 1: 4$; ocellars small........... Heteromeringia Czerny.

10. Ocellar bristles long; presutural dorsocentrals present................... 11

Ocellars short; no presutural dorsocentrals............. Sobarocephala Czerny.

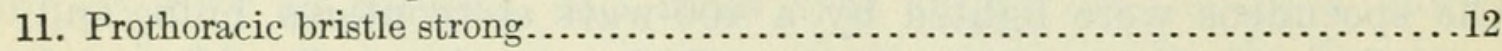

Prothoracic bristle short; three fronto-orbitals............... Apiochaeta Czerny.

12. Arista lanceolate, densely pubescent; three fronto-orbitals; four scutellar bristles.

Arista slender; four fronto-orbitals; six scutellars............ Alloclusia Hendel. 


\section{Genus ACARTOPHTHALMUS Czerny.}

Acartophthalmus Czerny, Wien. ent. Ztg., vol. 21, p. 256 (1902); vol. 22, p. 71 (1903).

Eyes provided with very fine scattered hairs; arista but little longer than antenna; postverticals strong and widely spaced; no cruciate frontal bristles, ocellars long, three fronto-orbitals, the foremost small and reclinate; prothoracic seta wanting, three postsutural dorsocentrals, no prescutellars, four scutellars, the basal pair strong; no preapicals; crossveins widely distant.

Genotype.-A. nigrinus Zetterstedt. This is the only genus having pubescent eyes, but this character requires high magnification to be detected. It is unique further in having a short arista, distant postverticals and a humeral break in the costa. Two species are known.

KEY TO THE SPECIES OF ACARTOPHTHALMUS.

Body black, legs brown or black, the front coxae somewhat paler; wings hyaline. (Europe, N. Amer.)............................. nigrinus Zetterstedt. Face, cheeks, anterior part of front, antennae, and mouthparts yellow; legs yellowish; wings infuscated anteriorly. (Europe.) .................. bicolor Oldenberg.

\section{ACARTOPHTHALMUS NIGRINUS Zetterstedt.}

(Fig. 10.)

Anthophilina nigrina Zetterstedt, Dipt. Scand., vol. 7, p. 2697 (1848).

Acartophthalmus nigrinus Czerny, Wien. ent. Ztg., vol. 22, p. 71 (1903).Malloch, Proc. Ent. Soc. Wash., vol. 20, p. 3 (1918).

Entirely blackish, the front coxae and halteres alone yellowish. No distinct vibrissae, about six uniform buccal bristles present; arista weakly pubescent, scarcely exceeding the length of the antenna, the basal joint thickened. Basal scutellar bristles about half the length of the convergent apical pair. Hypopygium very small. Wings grayish hyaline, auxiliary vein distinctly separated from the first vein, costal ratio, $3.8: 1.4: 1$, sections of fourth vein $1: 1.5$, of fifth vein $3: 1$. Length $2 \mathrm{~mm}$.

Distribution.-Twenty-two specimens, collected by Melander, from Petersham, Massachusetts; Moscow Mountain and Waha, Idaho; Wawawai, Olga, Mount Constitution, Quilcene, Blewett, Vashon, and Tacoma, Washington. Compared with a specimen from Admont, Austria, received from Prof. G. Strobl. Recorded from Sweden, Germany, and Austria.

\section{ACARTOPHTHALMUS BICOLOR Oldenberg.}

Açartophthalmus bicolor Oldenberg, Deut. ent. Zts., 1910, p. 284 (1910).

Lower part of head, antennae, anterior margin of front and legs yellowish; costal margin of wings infuscated; length $2 \mathrm{~mm}$.

Habitat.-Germany. Type in collection of L. Oldenberg, Berlin. 


\section{Genus ALLOMETOPON Kertesz.}

Allometopon Kertesz, Ann. Mus. Nat. Hung., vol. 4, p. 320 (1906).

Three reclinate orbitals, no postverticals, cruciate bristles very small, ocellars long; prothoracic bristle minute, three postsutural dorsocentrals, three supra-alars, four scutellars, no preapicals; arista thin; sections of fourth vein $1: 3$.

Genotype.-A. fumipenne Kertesz.

\section{ALLOMETOPON FUMIPENNE Kertesz.}

Allometopon fumipenne Kertesz, Ann. Mus. Nat. Hung., vol. 4, p. 320 (1906).

Head and thorax mostly yellow, abdomen mostly blackish, third antennal joint brown above, notum with brown anterior margin and abbreviated vitta; legs yellow; wings smoky, the costal margin darker; $3 \mathrm{~mm}$.

Habitat.-New Guinea. Type in Hungarian National Museum.

\section{ALLOMETOPON FLAVUM Lamb.}

Allometopon flavum LAмв, Trans. Linn. Soc., vol. 16, p. 311 (1914).

Described from Seychelles. The description is not available to us.

\section{Genus APIOCHAETA Czerny.}

Apiochaeta Czerny, Wien. ent. Ztg., vol. 22, p. 98 (1903).

Three fronto-orbitals, the first converging, postverticals present, no cruciates, ocellars long; prothoracic short, a presutural dorsocentral present, basal scutellars smaller than the distal pair; arista apical; crossveins distant, sections of fourth vein $1: 3$, posterior crossvein oblique, forming an acute angle with fifth vein.

Genotype.-A. bicolor Schiner, the species figured by Hendel in Czerny's paper.

KEY TO THE SPECIES OF APIOCHAETA.

Abdomen with exception of base shining black; wings subhyaline; thorax bivittate. (Chile.) bicolor Schiner.

Abdomen black only at tip; costal margin and discal spots blackish; thorax quadrivit-

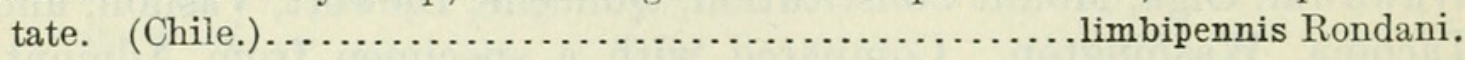

\section{APIOCHAETA BICOLOR Schiner.}

Heterochroa bicolor Schiner, Novara Dipt., p. 237 (1868).

A piochaeta bicolor CzenNY, Wien. ent. Ztg., vol. 22, p. 98, pl. 2, figs 6, 7 (1903).

Front yellow, face and cheeks whitish; arista pubescent; thorax reddish, with two posterior black vittae; pleurae with black stripe below notopleural suture; abdomen black except at base; legs yellow; halteres white; wings with pale brownish tinge; $4.5 \mathrm{~mm}$.

Habitat.-Chile. 


\section{APIOCHAETA LIMBIPENNIS Rondani.}

Peratochaetus limbipennis Rondani, Arch. di Canestrini, p. 43 (1863).

Apiochaeta limbipennis Czerny, Wien. ent. Ztg., vol. 22, p. 99 (1903).

Yellowish, an ocellar spot black; arista nearly bare; notum with four vittae, the inside pair extending into sides of scutellum, the outside pair extending into pleurae to the metathorax; abdomen tipped with black; legs brownish; halteres luteous; wings yellowish hyaline, the front margin, apex broadly, posterior crossvein, base posteriorly and sixth vein bordered with blackish; $4 \mathrm{~mm}$.

Habitat.-Chile.

\section{Genus CHAETOCLUSIA Coquillett.}

Chaetoclusia Coquillett, Proc. Ent. Soc. Wash., vol. 6, p. 93 (1904).-Malloch Proc. Ent. Soc. Wash., vol. 20, p. 5 (1918).

Three fronto-orbitals, the front pair convergent, no cruciate or postvertical bristles, ocellars small; no prothoracic, two dorsocentrals, no prescutellars; preapicals present; lunule covered; first vein setose.

Genotype.-C. bakeri Coquillett, the original species. The bristly first vein is the striking character of this genus.

KEY TO THE SPECIES OF CHAETOCLUSIA.

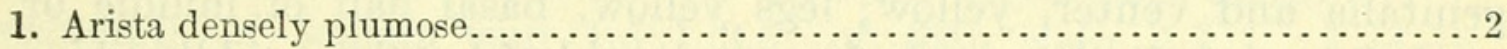

Arista finely pubescent or plumose; wings dark except at base.............. 3

2. Thorax wholly yellow; wings yellowish hyaline; front tibiae and tarsi brown; antennae yellow. (New Jersey.)....................... afflnis Johnson.

A horseshoe-shaped black mark around root of wing, notum bivittate; wings with central and apical vague clouds; posterior tibiae brownish basally; antennae with brown apex. (C. Amer.) ..................... bakeri Coquillett.

3. Pleurae yellow; legs yellow; notum marked with black or brown stripes.........4

Sternopleura with jet black circular spot; legs apically brownish; antennae luteous; notum yellow, a small spot between wings and scutellum. (Hayti)

nigromaculata, new species.

4. Notum black on the sides from and including humeri to the posterior margin; antennae yellow. (W. Ind.) ..................... xanthops Williston.

Notum quadrivittate; third antennal joint black or brown above............5

5. Femora not setose beneath; markings of body black; first vein with about 12 setulae. (Costa Rica).......................... quadrivittata, new species.

Front and middle femora with comb of setae beneath; markings brown; first vein with about 6 setulae. (Costa Rica)................. longefilata, new species.

\section{CHAETOCLUSIA AFFINIS Johnson.}

Chaetoclusia affinis Johnson, Psyche, vol. 20, p. 101 (1913).-Malloch, Proc. Ent. Soc. Wash., vol. 20, p. 5 (1918).

Clusia flava JoHnson, in part, New Jersey List (1899).

Male.-Head light yellow, palpi and antennae yellow, arista black, densely plumose, ocelli black. Thorax yellow, abdomen brownish, tip yellow. Legs yellow, anterior tibiae and tarsi brown. Halteres yellow. Wings yellowish hyaline. Length $2.5 \mathrm{~mm}$. 
Female.-Similar to male except that anterior tibiae and tarsi are black and the abdomen shining with an obscure dorsal line and black tip. Length $3 \mathrm{~mm}$.

Habitat.-New Jersey. Types in collection of C. W. Johnson Boston. The two types are the only specimens recorded of this species. We have not seen it, and quote the original description.

\section{CHAETOCLUSIA BAKERI Coquillett.}

(Fig. 16.)

Chaetoclusia bakeri Coquilletr, Proc. Ent. Soc. Wash., vol. 6, p. 93 (1904).Malloch, Proc. Ent. Soc. Wash., vol. 20, p. 5 (1918).

Head and its members yellow, polished, the bushy plumose apical arista and ocellar dot black, a brownish spot on outer side of third antennal joint; thorax yellow, sides of mesonotum black, prolonged downward in front of and behind each wing, and inward at each end of the mesonotum, the two ends connected by a second black vitta extending along the dorsocentral rows; scutellum yellow, with brownish sides or wholly black; abdomen black, the extreme base and sometimes a pair of spots at bases of segments four to six, the genitalia and venter, yellow; legs yellow, basal half of middle or hind tibiae usually brownish, femora devoid of bristles, middle tibiae bearing a stout apical spur on the inner side and the preapical bristle on the outer side; wings largely hyaline, apex brownish, this color extending to the middle of last section of third vein, an indistinct brownish cloud covering the crossveins, last section of fourth vein about seven times as long as preceding section; halteres yellow, all hairs and bristles yellowish; length $4 \mathrm{~mm}$.

Habitat.-Originally described from Nicaragua, type in National Museum. Five specimens before us, collected by Pablo Schild in Costa Rica.

.CHAETOCLUSIA LONGEFILATA, new species.

(Fig. 12.)

General color testaceous, antennae and palpi flavous, ocellar spot brown, arista brownish, three times the antennal length, openly pubescent, bristles concolorous with body at their place of origin, buccal hairs all small. Thorax with light brown sides between dorsocentral rows and root of wing, each stripe paler along its middle, humeri, central stripe, and scutellum testaceous, metanotum brownish, pleurae, halteres and base and more or less of fifth segment of abdomen flavous, middle of abdomen and apex castaneous, hypopygium large, inflexed, the valves testaceous and remarkably long, acuminate, reaching to base of abdomen; no prescutellars. Wings and veins yellowish, the anterior half of the apical half infumated, 
its veins brown, costal sections $6: 1.3: 1$, third vein ending at wingtip, sections of fourth vein $2: 1: 4$. Legs entirely yellowish, front and middle femora with close-fitting double flexor combs of short setae, middle tibiae with preapical bristle. Length $3 \mathrm{~mm}$.

Holotype.-Alhajuelo, Panama, 12 March, 1912, August Busck, Cat. No. 26260, U.S.N.M.

\section{CHAETOCLUSIA QUADRIVITTATA, new species.}

(Fig. 15.)

Female.-Front yellow, ocellar spot black, face and cheeks pale yellow; antennae and mouthparts yellow, the former dorsally piceous, arista slender, three and a half times the antennal length and deli. cately pubescent; head bristles long and brownish. Mesonotum testaceous with two blackish stripes on either side, extending from the neck, where they are joined, to the tip of the scutellum, where they are joined again; pleurae pale yellow except metapleurae which are brownish. Abdomen blackish except first and basal sides of fifth segments. Legs entirely yellow; apical spur of middle tibiae strong and black, no femoral comb of setae. Wings cloudy except on basal third, bristles of first vein distinct, costal ratio about $5: 1: 1$, segments of fourth vein $1.5: 1: 3.5$, of fifth vein $2.3: 1$. Length $3.5 \mathrm{~mm}$.

Types.-Three females, La Suiza de Turrialba, Costa Rica, AprilJuly (Pablo Schild). Type and one paratype in Melander collection, paratype in National Museum, Cat. No. 26261, U.S.N.M.

\section{CHAETOCLUSIA NIGROMACULATA, new species.}

Female.-Testaceous, the abdomen black except apex, a black spot between root of wing and scutellum, a large round black spot filling upper portion of sternopleura, metapleurae black anteriorly; antennae and mouthparts yellow, arista delicately plumose; bristles dark brown. Legs yellow, front and hind tibiae and tarsi brownish. Knobs of halteres whitish; wings brownish, paler at basal half, costal sections $5: 1: 1$, sections of fourth vein $3: 2: 8$, of fifth vein $1.4: 1$. Length $3.5 \mathrm{~mm}$.

Holotype.-Hayti, in Melander collection.

\section{CHAETOCLUSIA XANTHOPS Williston.}

(Fig. 14.)

Heteroneura xanthops Williston, in part, Trans. Ent. Soc. Lond., (1896), p. 386.Czerny, Wien. ent. Ztg., vol. 22, p. 100 (1903).

Head including antennae and mouthparts wholly yellow, arista loosely plumose, brown. Mesonotum black lateral to dorsocentral rows, centrally luteous, scutellum and metathorax yellow, pleurae 
flavous. Abdomen black except at base, hypopygium black, the long lamellae yellow. Legs yellow; hind tibiae slightly brownish, apical and preapical spurs of middle tibiae strong, underside of fore femora fimbriate with setae. Wings lightly brownish, stronger on apical third, first vein strongly setose, sections of fourth vein $5: 3: 15$, of fifth vein $5: 3$, fifth and anal veins not reaching margin. Length $3.5 \mathrm{~mm}$.

Habitat.-St. Vincent, West Indies. Described from a cotype specimen in the possession of Cornell University. Doctor Williston suggested that this species was a composite of several forms. In addition to the present form which seems most typical, the species is here segregated into Sobarocephala bistrigata Kertesz and S. xanthomelana, new species, which see.

\section{Genus CLUSIA Haliday.}

Clusia Haliday, Ann. Nat. Hist., vol. 2, p. 188 (1838).-Schiner, Fauna Austr., vol. 2, p. 36 (1864).-Czerny, Wien. ent. Ztg., vol. 22, p. 87 (1903).-Malloch, Proc. Ent. Soc. Wash., vol. 20, p. 3 (1918).

Heteromyza in part, Meigen, Syst. Bes., vol. 6, p. 45 (1830).-WALker, Ins. Brit., vol. 2, p. 163 (1853).

Macrochira Zettenstedt, Ins. Lapp., p. 784 (1838); Dipt. Sc., vol. 7, p. 2681 (1848). Peratochaetus in part, Rondani, Dipt. Ital. Prodr., vol. 1, p. 119 (1856); Arch. di Canestrini, vol. 3, pt. 1, p. 42 (1863); Bull. Soc. ent. Ital., vol. 6, p. 250 (1874).

Stomphastica in part, LoEw, Berl. ent. Zts., vol. 8, p. 336 (1864).

Relatively large species, three fronto-orbitals, the foremost pair converging, cruciate bristles present, postverticals absent, ocellars long, prothoracic bristles strong, two posterior dorsocentrals, four or six scutellars all long, no prescutellars, a row of mesopleural setae present, preapical bristle of middle tibiae very small, crossveins distant, lunule covered.

Genotype.-Clusia flava Meigen (Heteromyza.)

KEY TO THE SPECIES OF CLUSIA.

1. Abdomen without conspicuous black lateral spots; face yellow; pleurae usually

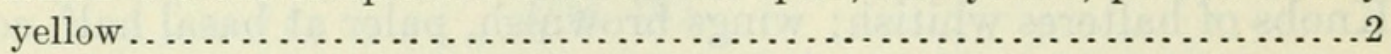

Abdomen with more or less conspicuous shining black lateral spots or stripes; face of male black, of female bimaculate; upper pleurae with black vitta....... 3

2. Arista very finely short-pubescent; antennae yellow; palpi yellow; pleurae not vittate with brown. (Western N. Amer.)........... occidentalis Malloch.

Arista evidently pubescent; upper side of antennal third joint and apex of female palpi blackish; pleurae usually brown above. (Eur.)......... flava Meigen.

3. Wings with two brown or blackish bands, one slightly beyond middle and the other at apex, connected along costa; male with bristles of anterior and posterior flexor surfaces of front femora subequal in length; sides of abdomen usually spotted instead of striped. (Eastern N. Amer.)............. czernyi Johnson.

Wings with only one brown band, the apical one; males with posterior flexor bristles of front femora much stronger than the anterior ones; sides of abdomen usually striped. (Eastern N. Amer.) ........................ lateralis Walker. 


\section{CLUSIA CZERNYI Johnson.}

(Fig. 3.)

Clusia czernyi Johnson, Psyche, vol. 20, p. 100 (1913).-Malloch, Proc. Ent. Soc. Wash., vol. 20, p. 4 (1918).

Mostly yellow, face of male black, of female with curving subantennal stripes, antennae, palpi and lower orbits pale yellow, arista very finely pubescent; an entire horizontal black vitta beneath notopleural suture; bristles of head and thorax strong and black; abdomen black and centrally yellowish, or yellow and laterally blackish, hypopygium globular and black, valves small and luteous, ovipositor yellow; legs yellowish, flexor bristles of front and middle femora of male moderate, those of posterior row longer than those of anterior; basal half of wings subhyaline, apical half marked with a blackish cloud paler in middle part of first and most of second posterior cells, sections of fourth vein nearly $1: 1: 2$, of fifth vein $3.5: 1$. Length $5 \mathrm{~mm}$.

Distribution.-Types from Maine, in collection of Boston Society of Natural History. Recorded from New Hampshire, Vermont, Massachusetts, New York, and Pennsylvania. Specimens, all taken during May or June, are before us from Waubamic, Ont.; Ithaca, Labrador Lake and McLean, N. Y.; Plummer Island, Md.; Dead Run, Va.

\section{ClUSia Flava Meigen.}

Heteromyza flava Meigen, Syst. Bes., vol. 6, p. 46 (1830).-Walker, Ins. Brit. Dipt., vol. 2, p. 163 (1853).

Heteroneura spurca Haliday, Ent. Mag., vol. 1, p. 171 (1838).-LoEw, Wien. ent. Monatsch., vol. 1, p. 51 (1857).

Stomphastica flava Loww, Zts. Entom. Bresl., p. 11 (1859); Berl. ent. Zts., vol. 7, p. 337 (1864).

Macrochira flava Zetterstedt, Ins. Lapp., p. 784 (1838); Dipt. Sc., vol. 7, p. 2683, (1848).

Peratochaetus lutescens Rondani, Bull. Soc. ent. Ital., vol. 6, p. 250 (1874).

Clusia flava Haliday, Ent. Mag., vol. 1, p. 171 (1838); Ann. Nat. Hist., vol. 2, p. 188 (1839).-Bore, Stett. ent. Zts., vol. 8, p. 331 (1847).-Schiner, Faun. Austr., vol. 2, p. 36 (1864).-Brauer, Zweifl. Mus. Wien., p. 92 (1883).-Mik, Wien. ent. Ztg., vol. 5, p. 101 (1886).-Czerny, Wien. ent. Ztg., vol. 22, p. 88 (1903).

Yellow, face, cheeks and mouthparts whitish, palpi of female apically dark, upper edge of third antennal joint blackish, arista evidently pubescent. Thorax testaceous, sometimes with brownish dorsocentral stripes, pleurae sometimes brown above. Abdomen usually yellow, sometimes a pair of spots on middle of segments two to five. Legs yellow, the somewhat broadened front tarsi of the female black. Wings light brownish, darker along costa, especially about end of second vein and apex, posterior crossvein clouded, sections of fourth vein $1: 2.5$, third and fourth veins parallel, be- 
coming somewhat convergent and at apex somewhat divergent. Length 5-6.5 mm.

Distribution.-The species is distributed over entire Europe.

15. CLUSIA LATERALIS Walker.

(Fig. 1.)

Helomyza (?) lateralis WALker, List Dipt., vol. 4, p. 1095 (1849).

Heteroneura spectabilis Loew, Wien. ent. Monatsch., vol. 4, p. 82 (1860); Berl. ent. Zts., vol. 7, p. 207; Cent. 4, 92 (1863).

Clusia lateralis Czerny, Wien. ent. Ztg., vol. 22, p. 89 (1903).-Johnson, Psyche, vol. 20, p. 101 (1913).-Malloch, Proc. Ent. Soc. Wash., vol. 20, p. 4 (1918).

Front brownish yellow, ocellar spot black, face of male black, of female with subantennal black stripes, cheeks and mouthparts pale yellow, antennae reddish yellow, arista sparsely pubescent. Notum testaceous with a brownish lateral stripe beginning one-fourth the way back from the neck and reaching the scutellum, pleurae pale yellow, the upper part with a complete broad black stripe. Abdomen mostly yellow, the posterior sides of segments two to four with triangular blackish marks, hypopygium black. Legs yellowish, the basal half of the hind tibiae brownish, postero-flexor bristles of the fore femora much stronger than those of the anterior row. Wings yellowish hyaline with a brownish spot on apical third, a slight clouding over basal two-thirds of fifth vein, costal ratio 4.5:1.3:1, sections of fourth vein $1: 1.2$, of fifth vein $5.3: 1$; halteres yellowish. Length 5 to $7 \mathrm{~mm}$.

Puparium.-Rufous, stigmal area less rugose than body and somewhat lighter in color, a central pair of divergent triangular stigmal processes, anus below stigmal area and surrounded by a black plate. Length $5 \mathrm{~mm}$.

Distribution.-The species has been recorded previously from Maine, Vermont, Massachusetts, New Jersey, Pennsylvania, Ottawa, Canada, District of Columbia, and Illinois. The female type is in the British Museum of Natural History. Specimens before us have come from the following localities: White Mountains, N. H.; Greenfield, Mass.; Ithaca and Gloversville, N. Y.; Brookside, N. J.; Pittsburgh, and Allegheny, Pa.; Plummer Island and Camp Meade, Md.; Dead Run, Va.; and Black Mountain, N. C. Most of the specimens were collected in late June and July.

16. CLUSIA OCCIDENTALIS Malloch.

(Fig. 2.)

Clusia occidentalis Malloch, Proc. Ent. Soc. Wash., vol. 20, p. 4 (1918).

Entirely yellowish, front, upper occiput and antennae luteous, face, cheeks and palpi whitish, arista very minutely pubescent, bristles strong. Thorax testaceous, coxae paler; abdomen in the 
dried specimens usually dark testaceous, the globular hypopygium and small valves luteous. Legs yellowish, of the flexor setae of front and middle femora those of the posterior row are much longer than those of the anterior set. Wings grayish hyaline, basal half of costal margin yellow, apical half blackish, connecting with the blackish tip of the wing, posterior crossvein surrounded by a blackish cloud, sections of fourth vein proportioned $1: 1: 2$, of fifth vein, $3: 1$. Length 5 to $7.5 \mathrm{~mm}$.

Distribution.-Type from Washington, in collection of Natural History Survey, Illinois University; allotype from California, in Aldrich collection. Specimens have been reviewed by us from Vancouver Island, B. C.; Olympia, Ilwaco, Vashon, Monroe, Dewatto, Mount Rainier, Olga, Everett, and Lake Cushman, Washington; and Viento, Oreg.

\section{Genus CLUSIODES Coquillett.}

Clusiodes Coquillett, Proc. Ent. Soc. Wash., vol. 6, p. 93 (1904).-Hendel Wien. ent. Ztg., vol. 29, p. 309 (1910).-Johnson, Psyche, vol. 20, p. 97 (1913).— Malloch, Proc. Ent. Soc. Wash., vol. 20, p. 5 (1918); Occ. Papers Bost. Soc. N. Hist., vol. 5, p. 47 (1922).

Heteroneura Fallen (not 1810), Dipt. Suec. Agromyz., p. 2 (1823).-Meigen, Syst. Bes., vol. 6, p. 126 (1830).-Macquart, Hist. Nat. Dipt., vol. 2, p. 587 (1835).- Zetterstedt, Dipt. Sc., vol. 7, p. 2786 (1848).-Schiner, Faun. Austr., vol. 2, p. 37 (1864).-Czerny, Wien. ent. Ztg., vol. 22, p. 73 (1903).Williston, Trans. Ent. Soc. Lond., 1896, p. 386 (1896).

Agromyza in part, Zetterstedt, Ins. Lapp., p. 790 (1838).

Clusiaria Malloch, Occ. Papers Boston Soc. N. Hist., vol. 5, p. 49 (1922).

Columbiella Malloch, Occ. Papers Boston Soc. N. Hist., vol. 5, p. 49 (1922).

Lunule exposed, two or three reclinate fronto-orbitals, cruciate bristles present, postverticals present in almost all the species, ocellars distinct; prothoracic bristle vestigial, dorsocentral formula 1-2 or 0-3, four or six scutellars; preapical present; crossveins approximate.

Genotype.-Heteroneura albimana Meigen.

KEY TO THE SPECIES OF CLUSIODES.

1. Three strong dorsocentral bristles present, the front pair presutural; at least front tarsi more or less black; wings with apical clouding. . . . . . . . . . . . . . . 2

Two strong dorsocentrals present, if a third pair is present it is small and postsutural; usually the front tarsi and generally the entire legs yellow; hypopygium relatively robust. (Subgenus Clusiaria Malloch)................... 10

2. Postvertical bristles entirely wanting, or if present very small; normally but two fronto-orbitals. (Subgenus Columbiella Malloch) ...................

Postvertical bristles present. (Subgenus Clusiodes Coquillett)..............

3. Thorax mainly rufous, subshining, bivittate with blackish; lamellae rounded, hairy but devoid of bunches of spines; basal two joints of male front tarsi black. (Eastern U. S.) (johnsoni Malloch) .............................

Mesonotum and upper pleurae black; lamellae three times as long as greatest breadth, the apical portion less than one-fourth as wide as the basal part, hairs of lamellae long; front metatarsus of male black; palpi yellow. (Atlantic

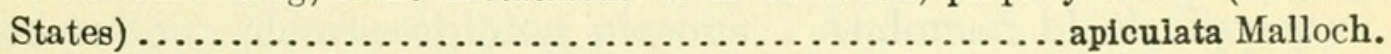


Thorax of female not so extensively darkened as of male; lamellae much flattened, broad at base, then rapidly narrowing and again gradually broadening out to the rounded tip, where on the lower inner side they bear a cluster of black spines, their hind margin ciliate with long hairs. (England).......... verticalis Collin.

4. Palpi usually entirely yellow; third joint of antennae usually yellow.

Palpi and third joint of antennae largely or wholly black.

johnsoni Malloch, s. str.

johnsoni, form nigripalpis Malloch.

5. Legs, including coxae, entirely piceous black; thorax and abdomen black, the humeri yellow: face, cheeks, antennae, and mouthparts yellowish. (N.Mex.)

nigra, new species.

Legs, at least in part, pale, usually only the first or second joints of front tarsi

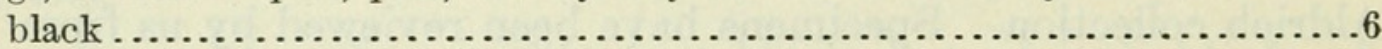

6. Normally three fronto-orbitals; hypopygium small, the valves short and rounded; vibrissae long and nearly straight, buccal hairs strong; thorax of female usually paler than of male. (Eur.; U. S.) (albimana Meigen) . . . . . . . . . . . . . 7

Normally two fronto-orbitals; hypopygium larger; vibrissae shorter and incurved, buccal hairs fine; thorax of both sexes colored alike; antennae pale.........8

7. Face, cheeks, mouthparts, and antennae yellow; notum and pleurae reddish; legs largely yellow; average length $3.5 \mathrm{~mm} . . . . .$. . albimana, form pallidior Loew.

Face, mouthparts, third joint of antennae, notum largely, pleurae, and most of legs blackish; average length $4 \mathrm{~mm} . . . . . . . .$. albimana, form obscurior Loew.

8. Hypopygial lamellae about twice as long as greatest breadth, the recurved apical portion half as wide as the basal part, hairs of lamellae short; face and palpi yellow; notum blackish. (Scotland)................... caledonica Collin.

Lamellae shorter, broader and more flattened at end and not recurved at tip....9

9. Palpi black, face yellowish, notum rufous, upper pleurae brown, posterior legs

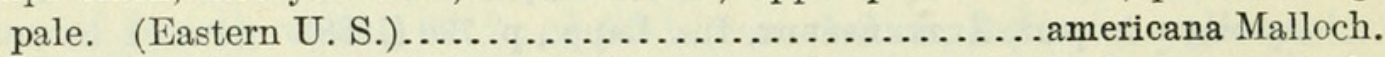

Palpi yellow, face somewhat darkened, thorax piceous, posterior legs extensively darkened. (England)..................................

10. Postverticals absent; cloud of wing commencing at end of first vein; thorax brownish yellow, with front margin, two vittae, scutellum and upper pleurae blackish; front tarsi and apices of front and hind tibiae infuscated. (Me.)

orbitalis Malloch.

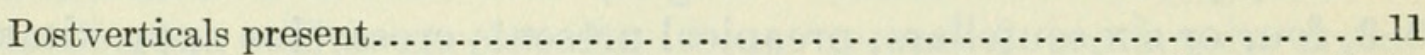

11. Mesonotum reddish, sometimes vittate posteriorly; pleurae mostly or entirely

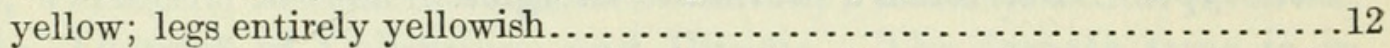

Mesonotum and pleurae mostly black, the sides of mesonotum narrowly yellow; legs partly dusky or dark .................................... 15

12. Face of male black; one, two, or more pairs of strong porrect vibrissae; female with face pale and single normal vibrissa; mesonotum usually without dark stripes, uppermost pleurae vittate; hypopygium large, globose, the valves large, flat, trapezoidal, uncinate apically and glabrous. (N. Amer.) (mela-

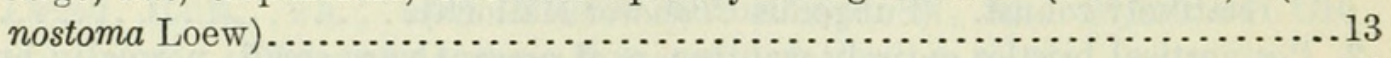

Face of both sexes not black; only one vibrissa........................ 14

13. Vibrissa single; usually three fronto-orbitals........... melanostoma Loew, s. str. Vibrissae of male plural; usually two fronto-orbitals.

melanostoma, form duplicata Malloch.

14. Face reddish; notum with four blackish stripes; pleurae not vittate; antennae brownish. (Eur.)............................... nubila Meigen.

Face pale yellow; notum with two dark stripes; upper pleurae vittate; antennae yellow, in female brownish at base of arista. (Eur.; Can.)..ruficollis Meigen. 
15. Costal margin of wings more or less smoky from end of first vein; cheek bristles small; antennae reddish. (Eur.; U. S.)................. geomyzina Fallen.

Wings smoky on apical third and not along middle of costa............. 16

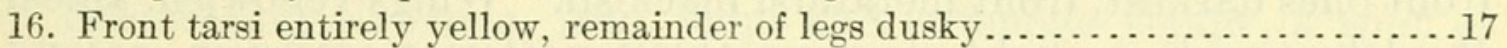

Front tarsi more or less black, tibiae and femora in part piceous or black..... 18

17. Face of male black; bristles of male cheeks strong; antennae yellow; hypopygium large. (Eur.; U. S.)............................... apicalis Zetterstedt.

Face of male white; buccal bristles and vibrissae moderate; antennae apically brown; hypopygium rather small. (N. H.)........... terminalis, new species.

18. Mesonotum shining; head reddish.................................. 19 Mesonotum opaque-dusted; head almost wholly black (male); femora and tibiae black except extremities; antennae blackish. (Mass.; N. Y.).

atra, new species.

19. Femora mainly black; antennae tipped with brown; wings with only the apical third clouded. (Eur.; N. Mex.)...................... pictipes Zetterstedt.

Femora yellowish; third antennal joint mostly or wholly blackish; a distinct cloud surrounding middle part of fifth vein (nitida, n. sp.).................. 20

20. Scutellum and mesonotum black, except for the usual pale lateral margin

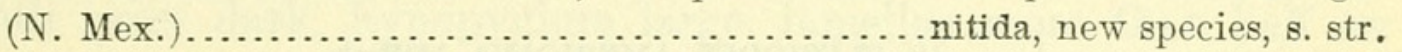
Scutellum and a large prescutellar spot yellowish. (Colo.).

nitida, var. scutellata, new variety.

\section{CluSiodes Albimana Meigen.}

(Fig. 7.)

Heteroneura albimana MeIgen, Syst. Bes., vol. 6, p. 128 (1830).-MACQUAŔ, Hist. Nat. Dipt., vol. 2, p. 588 (1835).-ZEtTerstedt, Dipt. Sc., vol. 7, p. 2790 (1840); vol. 12, p. 4817, var. b. (1855).-Loew, Wien. ent. Monats., vol. 1, p. 51 (1857); Berl. ent. Zts., vol. 8, p. 339 (1864).-Schiner, Faun. Austr., vol. 2, p. 38 (1864).-Perris, Ann. Soc. ent. France, vol. 10, p. 344 (1870).-Brauer, Zweifl. Mus. Wien, p. 92 (1883).-Girschner, Ent. Nachr., vol. 14, p. 98, figs. 5, 6 (1888).-Becker, Zts. Hym. Dipt., vol. 2, p. 313 (1902).-Czerny, Wien. ent. Ztg., vol. 22, p. 81, pl. 1, fig. 5 (1903).

Chusiodes albimana Johnson, Psyche, vol. 20, p. 98 (1913).-Malloch, Proc. Ent. Soc. Wash., vol. 20, p. 6 (1918); Occ. Papers Bost. Soc. N. Hist., vol. 5, p. 47 (1922).

Agromyza geomyzina Fallén, Dipt. Suec. Agrom., p. 3, var. b. (1823).-ZetterSTEDT, Ins. Lapp., p. 790, var. c. (1838).

Heteroneura pictipes Schiner, Faun. Austr., vol. 2, p. 37 (1864).-Handlirsch, Verh. Ges. Wien., vol. 34, pl. 5, fig. 12 (1884).

Form pallidior Loew. Front luteous, face, cheeks, mouthparts, and antennae yellow, upper occiput piceous, vibrissae relatively smaller. Notum testaceous, sometimes piceous between humeri, two narrow dark vittae just outside dorsocentral rows; abdomen black. Legs yellowish, front tibiae and front metatarsi brownish. Wings and other details as in darker form. Length 3.5-4 mm.

Form obscurior Loew. Front blackish brown, orbits yellow, face and palpi blackish; antennae yellow, last joint blackish, arista black and very minutely pubescent; one pair of very strong porrect oral vibrissae; usually three fronto-orbitals, the uppermost weak, bristles black. Notum blackish brown, shining between humeri, lateral margins yellow, pleurae shining piceous. Abdomen black, hypopy- 
gium small, valves rounded, wider than long. Front coxae whitish, posterior ones yellow, extremities of femora yellow, tibiae brown, front ones darkest, front metatarsi blackish. Wings yellowish, apical third brownish, a slight clouding about posterior crossvein, second and third veins nearly parallel, third and fourth veins centrally divergent and apically slightly convergent; costal ratio $6: 1.3: 1$, sections of fourth vein $2.5: 1: 6$, of fifth vein $1: 1$; halteres whitish. Length $4 \mathrm{~mm}$.

Distribution.-Europe and North America. Specimens of both extremes examined from Germany. There are no North American specimens before us like the form obscurior, but the paler form is represented from Potlatch and Everett, Wash., and Priest Lake, Idaho (Melander). The paler form is typical, and in Europe intergrades with the darker according to Czerny. The type of albimana is supposed to be destroyed.

\section{CLUSIODES AMERICANA Malloch.}

Clusiodes americana Malloch, Occ. Papers Bost. Soc. N. Hist., vol. 5, p. 48 (1922).

Male.-In the albimana group with three strong dorsocentrals. Head yellow, the upper occiput brown, antennae yellow, palpi brown, arista short, twice the antennal length, evidently pubescent, two fronto-orbitals, the cruciate bristles inserted in advance of the posterior pair, vibrissa small and curved, three fine buccal hairs, bristles of head and thorax brown. Thorax reddish yellow, darker along sides of notum and along upper half of pleurae. Abdomen black, hypopygium fairly large, the black valves as in Collin's figure of gentitis, about twice as long as wide, finely hairy, the blunt apical portion half the width of the base. Legs yellow, the front metatarsi alone black. Wings largely smoky, a central hyaline crossband, first posterior cell widest at middle, sections of costa about $3: 1: 0.5$, of fourth vein $2: 1: 6$, apical section of fifth vein a little shorter than the basal; halteres white. Length $3 \mathrm{~mm}$.

Female.-Apex of antennae dusky; front tarsi brown.

Recorded from Maine, New Hampshire, Vermont, and Maryland. Specimens before us from Mount Washington, N. H. (Mrs. Slosson), labeled by Coquillett as Heteroneura, new species, Jeannette, Pa. (Henry Klages), and several from Dead Run, Va. (Shannon), collected with $C$. johnsoni. A large female taken by Shannon in May at Ithaca, N. Y., is darker, the sides of the thorax almost blackish above the lower pleurae, the dark part of the wings fuliginous and the posterior legs luteous beyond the base. It is quite possible that this species is only a mutation of $C$. johnsoni, as it differs merely in the presence of small postverticals. If this should prove to be the case the subgenus Columbiella becomes untenable, a conclusion reached by the writers before the appearance of Malloch's last paper. 


\section{Clusiodes CaLEdonica Collin.}

Heteroneura caledonica Collin, Ent. Mag., vol. 48, p. 106, fig. 1 (1912).

Resembling albimana, face, palpi and antennae yellow, a spot at base of arista, two fronto-orbitals, the anterior one-half the length of the posterior, cruciate bristles midway between the fronto-orbitals, vibrissa not spike-like. Thorax of both sexes dark, hypopygium large, lamellae twice as long as wide and recurved apically. Posterior legs yellowish.

Habitat.-Scotland.

20. CLUSIODES GENTILIS Collin.

Heteroneura gentilis Collin, Ent. Mag., vol. 48, p. 107, fig. 2 (1912).

Resembling albimana, face darkened, palpi and antennae yellow, a spot at base of arista, two fronto-orbitals, the cruciate bristles nearer the posterior fronto-orbitals, vibrissae not spike-like. Thorax of both sexes dark, hypopygium large, lamellae more than half as wide at tip as at base and not recurved. Posterior legs darkened. Wing cloud relatively restricted.

Habitat.-England.

21. CLUSIODES NIGRA, new species.

Male.-Front brownish, orbits paler, cheeks, mouthparts and antennae yellowish, the last brownish at the insertion of the black, microscopically pubescent arista; four rather long buccal setae, vibrissae broken, but judging from the socket not excessive, three fronto-orbitals, postverticals present, head bristles strong and black. Notum black, humeri and lateral margin whitish, pleurae entirely black, one strong presutural and two postsutural dorsocentrals. Abdomen black, hypopygium small, globose, lamellae rounded triangular. Legs piceous, front coxae whitish, posterior coxae fuscous, hind tarsi brown. Wings subhyaline, the apical third and the area about the two crossveins brownish, sections of the evanescent fifth vein 1.1:1; halteres yellow. Length $4 \mathrm{~mm}$.

Holotype.-In National Museum collection, from Rio Ruidoso, Whîte Mountains, New Mexico, altitude 6,500 feet, August, collected by C. H. T. Townsend, Cat. No. 26262, U.S.N.M.

\section{CLUSIODES (CLUSIARIA) APICALIS Zetterstedt.}

Heteroneura geomyzina, var. apicalis ZetTenstedt, Dipt. Sc., vol. 7, p. 2189 (1848). Heteroneura geomyzina MeIgen, Syst. Bes., vol. 6, p. 129, in part (1830).-Loew, Wien. ent. Monats., vol. 1, p. 54 (1857); Berl. ent. Zts., vol. 8, p. 345 (1864).

Hereroneura apicalis Czenny, Wien. ent. Ztg., vol. 22, p. 79, pl. 1, figs. 3, 6 (1903).

Front brownish, antennae yellow, brownish at insertion of the microscopically pubescent arista, orbits and posterior portions of the cheeks yellowish, face and anterior portions of cheeks forming a black triangle, mouthparts whitish, buccal hairs almost as stout as the 
vibrissae, head bristles strong and black, three fronto-orbitals, postverticals long. Notum blackish, with a whitish lateral stripe extending full length, pleurae piceous, two strong dorsocentrals, and a small adjacent anterior one. Abdomen blackish, hypopygium robust, valves large, quadrate, nearly glabrous, the middle of the apical edge with a strong finger-like process. Coxae white, legs uniformly yellowish. Wings grayish with apical third between costa and third veins infuscated, third and fourth veins centrally divergent and apically convergent, sections of costa $6: 1.7: 1$, of fourth vein $1.4: 1: 4$, of the evanescent fifth vein $1.2: 1$; halteres whitish. Length $3 \mathrm{~mm}$.

Distribution.-A robust species, reported from Sweden to Germany. The specimens described above are from Moscow Mountain, Idaho, collected by Shannon and Melander. Malloch's record of the occurrence of this species in Illinois probably concerns $C$. terminalis.

\section{CLUSIODES (CLUSIARIA) ATRA, new species.}

(Fig. 9).

Male.-Front piceous except the yellowish orbits and anterior fourth, face, cheeks, and occiput blackish, facial orbits white; antennae blackish, arista one and one-half times the antennal length and microscopically pubescent; mouthparts yellow, vibrissa single, short and curved, buccal setae strong; three fronto-orbitals. Notum dull black, humeri and lateral margin white, pleurae shining black. Abdomen black, hypopygium semiglobose, valves very large, incised subapically and with round end. Legs blackish except at knees, posterior tarsi brownish. Wings grayish hyaline, with an infumation on the apical third between the costa and the third vein, costal ratio $4.5: 1.3: 1$, sections of fourth vein $1.2: 1: 4.3$, of fifth vein $1.1: 1$, fifth vein scarcely attaining margin, second and third veins diverging; halteres whitish. Length $3.6 \mathrm{~mm}$.

Type.-Greenfield, Mass., 1 June, 1914 (Melander). Paratype, Ithaca, N. Y., 3 May, 1903 (Cornell University).

\section{CLUSIODES (CLUSIARIA) GEOMYZINA Fallén.}

Heteroneura geomyzina FAllén, Dipt. Suec. Agromyz, p. 2, excl. var. b (1823).Meigen, Syst. Bes., vol. 6, p. 129, male (1830).-Zetterstedt, Dipt. Sc., vol. 7, p. 2788 (1848).-Schiner, Faun. Austr., vol. 2, p. 38 (1864).-Loew, Berl. ent. Zts., vol. 8, p. 345 (1864).-Czerny, Wien. ent. Ztg., vol. 22, p. 77 (1903). Agromyza geomyzina Zetterstedt, Ins. Lapp., p. 790, var. $b$ (1838).

Clusiodes geomyzina Johnson, Psyche, vol. 20, p. 97 (1913).-Malloch, Proc. Ent. Soc. Wash., vol. 20, p. 6 (1918).

Clusiaria geomyzina Malloch, Occ. Papers Bost. Soc. Nat. Hist., vol. 5, p. 48 (1922).

Heteroneura alpina Loew, Wien. ent. Monats., vol. 1, p. 53 (1857); Berl. ent. Zts., vol. 8, p. 344 (1864).-Girschner, Ent. Nachr., vol. 14, p. 98, figs. 7, 8 (1888).

Robust. Head blackish, the orbits, antennal region and posterior cheeks yellowish, mouthparts yellow, antennae blackish on apical 
half, arista one and a half times the antennal length, microscopically pubescent, three fronto-orbitals, the cruciate bristles near the middle fronto-orbitals, postverticals present. Thorax black, the humeri and side margins of mesonotum yellow, two strong and one weak dorsocentrals, pleurae piceous. Abdomen black, hypopygium robust, valves large, flat, rhomboidal. Legs dull yellow. Halteres including stem whitish. Wings dusky along costa, about crossveins and in apical region excepting the hind margin, third and fourth veins slightly converging in the apical cloud, anterior crossvein a little beyond middle of discal cell, fifth vein reaching margin, its sections proportioned $6: 5$. Length $3.25 \mathrm{~mm}$.

Distribution.- Sweden and Norway to Austria and Italy. Recorded by Johnson from Maine. The present specimens were collected by R. C. Shannon at Mount Lemon, South Catalina Mountains, Arizona at an altitude of 8,000 feet.

\section{CLUSIODES (CLUSIARIA) MELANOSTOMA Loew.}

(Fig. 4).

Heteroneura melanostoma Loew, Berl. ent.Zts., vol. 8, p. 260; Cent. 5.97 (1864).Czerny, Wien. ent. Ztg., vol. 22, p. 77 (1903).

Clusiodes melanostoma Johnson, Psyche, vol. 20, p. 98 (1913).-Malloch, Proc. Ent. Soc. Wash., vol. 20, p. 5 (1918).

Clusiaria melanostoma Malloch, Occ. Papers Bost. Soc. Nat. Hist., vol. 5, p. 48 (1922).

Clusiaria duplicata Malloch, Occ. Papers Bost. Soc. Nat. Hist., vol. 5, p. 49 (1922).

Male.-Front testaceous, the ocellar spot black, antennae yellowish, dusky at apex, arista very lightly pubescent, one and one-half times the antennal length, face black, anterior half of cheeks black, posterior half, orbits and mouthparts whitish; one, two or more pairs of very strong vibrissae equal in length and projecting as far as length of head, three buccal bristles, three or two fronto-orbitals. Mesonotum rufous, the sides reddish brown, humeri, notopleural suture and upper pleurae deeper brown, lower pleurae yellow, metanotum more or less blackish. Abdomen blackish, hypopygium large, globose, valves prominent, distorted rhomboidal, the outer apical angle prolonged in a spoon-shaped process, the inner apical angle projecting in a strong thumb-like piece. Wings grayish, apical third between costa and fourth vein irruscated, a slight infuscation about posterior crossvein, sections of eosta $5: 1.5: 1$, of fourth vein $1.3: 1: 4.5$, of fifth vein $1.3: 1$; halteres white.

Female.-Face yellowish, a single normal vibrissa.

Distribution.-Recorded localities include Maine, New Hampshire, Vermont, Massachusetts, New Jersey, Maryland and Canada. The type, from New York, is in Agassiz Museum of Harvard University. The specimens before us have come from Mount Washington, N. H.; 
Ithaca and Labrador Lake, N. Y.; Plummer Island and Camp Meade, Md.; Dead Run, Va.; Algonquin, Ill.; and Pullman, Wash.

A male from Lake Waha, Idaho, differs in having a single normal vibrissa and three fronto-orbitals. The thumb-like process at the apex of the genital valves is stronger than in the Eastern specimens. It is left with this species pending the securing of additional material. Possibly the Pullman record above given belongs to this race, as it is based on a single female specimen.

The name Heteroneura flavifacies Coquillett, given in Smith's list of New Jersey insects, refers to the female of this species.

Recently Malloch has attempted to segregate from this as a distinct species under the name of duplicata those forms which lack the uppermost fronto-orbital and whose males possess two vibrissae. The extensive series of specimens before us show that these and the other characters mentioned by Malloch are variable and are not correlated. In a pair from Dead Run, Va., mounted together by Shannon, the male shows two fronto-orbitals, with three vibrissae on one side and two on the other, while the female has three fronto orbitals. Another male has four stout vibrissae, others show two on one side and one on the other. Several specimens have three frontoorbitals on one side and two on the other. An individual may have three fronto-orbitals and two vibrissae. The name duplicata therefore does not have even varietal rank.

26. CLUSIODES (CLUSIARIA) NITIDA, new species.

(Fig. 6.)

Female.-Front yellow, antennae yellowish, last joint black, arista almost bare, nearly twice as long as antenna, face and cheeks whitish, one vibrissa, three buccal setae, three fronto-orbitals, cruciate bristles midway between the middle and front orbitals, head bristles including postverticals strong and black. Thorax largely piceous and shining, a conspicuous white vitta covering humeri and extending to base of wing, one weak and two strong postsutural dorsocentrals. Abdomen entirely black. Legs fuscous, front tarsi black. Wings hyaline with two brownish spots, one on apical third between fourth vein and costa, and one about posterior crossvein, extending basally along fifth vein, third and fourth veins centrally divergent and apically convergent, sections of costa $4.5: 1.3: 1$, of fourth vein $1.5: 1: 4.5$, of the evanescent fifth vein $1.2: 1$; Halteres white. Length $4 \mathrm{~mm}$.

Holotype.-Hill above Beulah, N. Mex., August 9, T. D. A. Cockerell collector, in National Museum, Cat. No. 26263, U.S.N.M.

Var. scutellata, new variety. A female from Boulder, Colo., also collected by Dr. T. D. A. Cockerell, is simular to the preceding, but the mesonotum has a large quadrate yellow spot at the base of the 
yellow scutellum, sending three thin yellow stripes forward, one of which is median, the two others in the dorsocentral rows; pleurae reddish yellow, wings lacking the infuscation about the posterior crossvein.

Holotype.-In National Museum, Cat. No. 26264, U.S.N.M.

\section{CLUSIODES (CLUSIARIA) NUBILA Meigen.}

Heteroneura nubila Meigen, Syst. Bes., vol. 6, p. 127 (1830).-Czerny, Wien. ent. Ztg., vol. 22, p. 76 (1903).

Differs from ruficollis Meigen (p. 22), in having the face ferruginous, antennae more or less brown, pleurae without the superior dark vitta, and notum quadrivittate. 3.5 to $4 \mathrm{~mm}$.

Habitat.-Germany and Austria.

\section{CLUSIODES (CLUSIARIA) ORBITALIS Malloch.}

Columbiella orbitalis Malloch, Occ. Papers Bost. Soc. Nat. Hist., vol. 5, p. 50 (1922).

Head yellow, darker above, antennae and palpi yellow; three fronto-orbitals, no postverticals. Thorax brownish yellow, the front margin, two vittae, scutellum and upper pleurae blackish; two dorsocentrals. Abdomen black. Legs yellow, the front and hind tibiae at apex and the front tarsi infuscated. Cloud of wing extending from end of first vein to apex. $4 \mathrm{~mm}$.

A single female is known, from Maine, now located in the Boston Society of Natural History.

29. CLUSIODES (ClUSIARIA) PICTIPES Zetterstedt.

Heteroneura pictipes Zettenstedt, Dipt. Sc., vol. 12, p. 4816 (1855).-Czerny, Wien ent. Ztg., vol. 22, p. 80 (1903).

Clusiodes pictipes Johnson, Psyche, vol. 20, p. 98 (1913).-Malloch, Proc. Ent. Soc. Wash., vol. 22, p. 7 (1918).

Clusiaria pictipes Malloch, Occ. Papers Bost. Soc. N. Hist., vol. 5, p. 48 (1922).

Front brownish, antennae luteous, the third joint brown, face and cheeks whitish, mouthparts brownish; one pair of moderate vibrissae and three buccal setae, three fronto-orbitals, postverticals present. Notum black, a conspicuous white vitta covering humeri and extending to base of wing, pleurae entirely black, one weak postsutural and two strong dorsocentrals. Abdomen entirely black. Legs piceous, the coxae, base of femora, knees, and posterior tarsi yellowish brown. Wings nearly hyaline, a brownish apical spot between costa and fourth vein, sections of costa $4.6: 1.2: 1$, sections of fourth vein $1.4: 1: 3.5$, of fifth vein $1.4: 1$; halteres white. Length $4 \mathrm{~mm}$.

Distribution.-Sweden and United States. C. pictipes has not been recovered in Europe since Zetterstedt's time. Johnson's record of it in the New Jersey list refers to Heteromeringia nitida. Mrs. Slosson has reported it on Coquillett's determination from New Hampshire. 
A specimen from Cloudcroft, N. Mex., was identified as pictipes on superficial comparison with specimens in the United States National Museum so determined by Coquillett. Johnson and Malloch are doubtful if Zetterstedt's species actually occurs in America, and the question can not be settled in the absence of typical European material. However, since Zetterstedt's description applies well to our form, there is nothing to be gained by bestowing a new specific name on the specimens from the United States. Malloch tabulates the species as having a light colored thorax.

\section{ClUSiodes (ClUSiaria) RUFicollis Miegen.}

Heteroneura ruficollis Meigen, Syst. Bes., vol. 6, p. 128 (1830).-Zetterstedt, Dipt. Sc., vol. 7, p. 2789 (1848).-Loew, Wien. ent. Monats., vol. 1, p. 52 (1857); Berl. ent. Zts., vol. 8, p. 343 (1864).-Schiner, Faun. Austr., vol. 2, p. 38 (1864).-Czerny, Wien. ent. Ztg., vol. 22, p. 75 (1903).

Clusiaria ruficollis Malloch, Occ. Papers Bost. Soc. N. Hist., vol. 5, p. 48 (1922). Heteroneura laterella Zetterstedt, Dipt. Sc., vol. 7, p. 2791 (1848).

Front yellow, ocellar spot black, face, cheeks, mouthparts and antennae pale yellowish, arista pale and finely pubescent, one vibrissa, three fronto-orbitals, postverticals strong. Notum testaceous, pale laterally, pleurae rufous above, one small and two large postsutural dorsocentrals. Abdomen black, hypopygium greatly swollen, the valves as in melanostoma. Legs yellowish except the brownish front tarsi. Wings nearly hyaline, a slight infumation on apical third between costa and third vein, sections of costa proportioned $5: 1.2: 1$, of fourth vein $1.2: 1: 4.5$, of fifth vein $1.3: 1$, third and fourth veins slightly convergent at tip; halteres whitish. Length $3 \mathrm{~mm}$.

Distribution.-Northern and Central Europe. We have specimens from Waubamic, Ontario, collected by H. S. Parish, which agree with the diagnoses of the European species except that they lack the variable brown vittae just outside the dorsocentral rows. These have furnished the preceding description, but in the absence of European material for comparison may not be identically the same form. They may represent a pale faced mutation of our common C. melanostoma.

31. CLUSIODES (CLUSIARIA) TERMINALIS, new species.

(Fig. 8.)

Clusiodes apicalis Malioch, Proc. Ent. Soc. Wash., vol. 20, p. 6 (1918).

Clusiaria apicalis Malloch, Occ. Papers Bost. Soc. N. Hist., vol. 5, p. 48 (1922).

Male.-Front dusky yellow, posterior half darker, antennae yellow, the third joint infuscated, arista yellow, microscopically pubescent, face, the broad cheeks and mouthparts whitish, vibrissa moderate, two strong buccal bristles three-fourths as long as the vibrissa, head bristles strong and black, three fronto-orbitals, postverticals present. Notum dull castaneous, humeri and lateral vitta 
white, pleurae entirely shining castaneous; three postsutural dorsocentrals. Abdomen piceous, hypopygium moderately large, the lamellae elongate triangular with bluntly rounded tip and devoid of long hairs. Legs yellow. Wings nearly hyaline, a brownish spot on apical fourth between costa and fourth vein, third vein bent, sections of costa proportioned 4.5:1.5:1, of fourth vein $1.3: 1: 4$, of fifth vein 1.1:1; halteres white. Length $3 \mathrm{~mm}$.

Holotype.-White Mountains, New Hampshire, Morrison, in National Museum, Cat. No. 26265, U. S. N. M. Malloch's record of the occurrence of $C$. apicalis Zetterstedt in Illinois probably has reference to this species.

\section{ClUSiOdES (COLUMBIELla) APICUlata Malloch.}

Columbiella apiculata Malloch, Occ. Papers Bost. Soc. N. Hist., vol. 5, p. 49 (1922).

Male.-Front brown, orbits scarcely lighter, occiput piceous, face and cheeks yellowish, mouthparts pale yellow, antennae blackish except at base, the arista minutely pubescent; two fronto-orbitals, the cruciate bristles inserted at the level of the upper fronto-orbital, buccal hairs fine. Notum black, subshining, upper half of pleurae shining black, lower half pale yellow, pectus brown, three dorsocentrals. Abdomen black, hypopygium large, its valves unusually long and hairy, crossing beneath the abdomen. Legs yellow, front metatarsus black, hind femora and tibiae centrally brownish. Wings variegated hyaline and smoky, dark on apcial two-fifths and along third and fifth veins near their respective crossveins, the hyaline middle area encroaches on the apical cloud along the middle of the submarginal and first posterior cells, sections of costa $6: 2: 1$, of fourth vein $1: 0.6: 4$, of fifth vein $1: 1$; halteres white. Length $3 \mathrm{~mm}$.

This description is drawn from a specimen from the North Fork of the Swannanoa, Black Mountains, N. C., May (Banks) from the United States National Museum. Malloch reoords the species from New Hampshire and Vermont.

\section{CLUSIODES (COLUMBIELLA) JOHNSONI Malloch.}

(Fig. 5.)

Columbiella johnsoni Malloch, Occ. Papers Bost. Soc. N. Hist., vol. 5, 49 (1922). Columbiella nigripalpis Malloch, Occ. Papers Bost. Soc. N. Hist., vol. 5, p. 49 (1922).

Male.-In the albimana group, with three dorsocentrals. Front piceous, the orbits yellow, face black, pollinose, facial orbits and gena pruinose, upper occiput blackish; base of antennae yellow, third joint almost wholly black, arista brown, twice the antennal length, minutely but closely pubescent; palpi black, proboscis yellow; two fronto-orbitals, the cruciate bristles between the posterior pair, no postverticals, vibrissa single, porrect and very strong, buccal hairs 
strong. Mesanotum blackish, the sides yellow, pleurae and pectus piceous, a little paler about the posterior coxae; four scutellars, sides of metanotum yellowish, Abdomen entirely black except the claspers, hypopygium globose, valves rounded trapezoidal, hairy. Legs mostly yellow, a spot above front knees, the front tibiae and first two joints of front tarsi black, postero-flexor bristles of anterior femora strong. Halteres white; wings grayish hyaline, smoky on apical two-fifths except along hind margin, third and fifth veins clouded near their respective crossveins, sections of costa proportioned $7: 2: 1$, of fourth vein $5: 4: 17$, of fifth vein $6: 5$, first posterior cell widest just beyond middle. Length $3-4 \mathrm{~mm}$.

Female.-Front, face, cheeks, mouthparts and antennae yellow, upper occiput and ocellar region piceous, antennae tipped dark spot; vibrissae less firm and more curved. Notum mostly rufous, a black stripe just external to dorsocentral rows, the two connected in front, extreme sides yellow, lower pleurae yellow, middle pleurae rufous, a subsutural black stripe. Abdomen black, the ovipositor yellow. Legs yellow, front tibiae and front metatarsus black.

Distribution.-Numerous specimens, all collected by R. C. Shannon, on Plummer Island, Md., Dead Run, Va., and Labrador Lake, N. Y., bearing dates from May 14 to September 19; also from Waubamic, Ont. (H. S. Parish), and Ottawa. Described by Malloch from Maine, New Hampshire, Vermont, Massachusetts, and Maryland.

The many specimens show much intergrading variation in color. The description of the male is based on the form described by Malloch as nigripalpis; that of the female is based on the form johnsoni. In one male a second pair of oral vibrissae is developed as is commonly the case in melanostoma.

34. CLUSIODES (COLUMBIELLA) VERTICALIS Collin.

Heteroneura verticalis Collin, Ent. Mag., vol. 48, p. 107 (1912).

Resembling albimana, normally two fronto-orbitals, post-verticals lacking. Thorax of female less extensively darkened than a male, hypopygial lamellae flattened, broad at base, then rapidly narrowing and again gradually broadening out to the rounded tip, where on the lower inner side they bear a cluster of black spines, the lower margin ciliate with long hairs.

Habitat.-England.

\section{Genus CZERNYOLA Bezzi.}

Czernyola Bezzi, Wien. ent. Ztg., vol. 26, p. 52 (1907).

Craspedochaeta Czerny, Wien. ent Ztg., vol. 22, p. 103 (1903).-Kertesz, Ann.

Mus. Nat. Hung., vol. 1, p. 569 (1903).

Lunule covered; three or four reclinate fronto-orbitals, cruciate bristles present and located on the orbits between the second and 
third fronto-orbital bristles counting from in back, postverticals present, ocellars short, prothoracic vestigial, one or two postsutural dorsocentrals, apical scutellars divergent, preapicals present on all tibiae; crossveins approximate.

Genotype.-C. transversa Czerny. This genus is unique in the location of the cruciate bristles on the frontal orbits. Czerny originally described the genus under the name Craspedochaeta, but Bezzi called attention that this name had already been used by Macquart in 1851 for a genus of the Anthomyiidae.

KEY TO THE SPECIES OF CZERNYOLA.

1. Third and fourth veins convergent; four fronto-orbitals; wings infumated on apical half, weaker behind and stronger about crossveins; legs yellow; mesonotum and pleurae marked with black and yellow. (Peru)...... transversa Czerny.

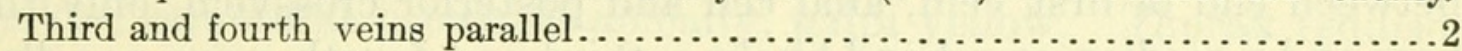

2. Four fronto-orbitals; wings hyaline; notum black, pleurae yellow. (Costa

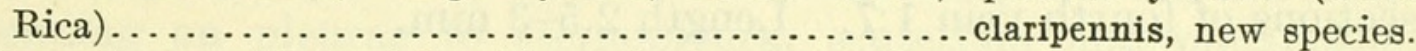

Three fronto-orbitals; infumation of wings extending into basal half; pleurae

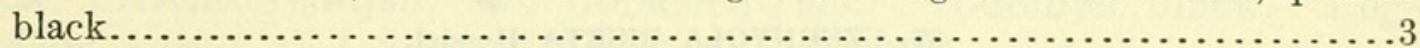

3. Darker portion of wings divided by a transverse paler band $\ldots \ldots \ldots \ldots \ldots \ldots \ldots$

Wings not marked with central paler fascia............................

4. Legs yellow, tarsi and middle of hind tibiae brown; head largely pale, male.

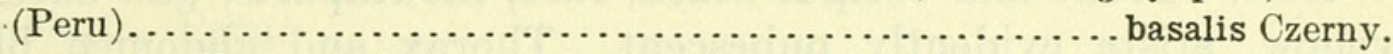

Front coxae, all of anterior femora, apical two-thirds of hind femora and the hind tibiae black, femora not fimbriate; head black, palpi piceous, antennae blackish at apex, female. (Costa Rica)................ fascipennis, new species.

5. Wings brown, more intensive between costa and posterior crossvein; legs yellow, hind femora with brown preapical ring; face, mouthparts and antennae, yellow, occiput, thorax and abdomen black, male. (Formosa).... biseta Hendel.

Wings uniformly infumated except at paler base; legs yellow in male, or mostly black in female, underside of femora setose; face, antennae and palpi yellow, male, or largely dark, female. (Bolivia; Costa Rica)............ atra Kertesz.

\section{CZERNYOLA ATRA Kertesz.}

(Fig. 11.)

Craspedochaeta atra Kertesz, Ann. Mus. Hung., vol. 1, p. 570 (1903).

Male.-Front blackish, anterior portion reddish to yellow, face cheeks, mouthparts, and antennae pale yellow, arista evidently pubescent, three times antennal length; bristles yellow to brown, three fronto-orbitals, vibrissa long and slender, about five uniform buccal hairs. Thorax uniformly black and shining, bristles yellow to brown, two small dorsocentrals placed well back. Abdomen black, lamellae long. Legs, including coxae, pale yellow, the hind femora and tibiae somewhat infuscated at apices, under side of femora with long regular yellow bristles. Wings uniformly infumated except at paler base, sections of costa $4: 1.4: 1$, of fourth vein $1: 1: 4$, of fifth vein $1.2: 1$; halteres whitish. Length $2.5 \mathrm{~mm}$.

Female.-Head, including mouthparts, black, antennae tipped with black, bristles black. Legs with front coxae, anterior femora, 
apical two-thirds of hind femora and posterior tibiae black, femoral bristles shorter and black.

Distribution.--Originally described from Bolivia. Eleven males and fourteen females received from Pablo Schild, La Suiza de Turrialba, Costa Rica. Were it not that the dimorphism is constant according to sex it would be surmised that two species are here.

\section{CZERNYOLA BASALIS Czerny.}

Craspedochaeta basalis Czerny, Wien. ent. Ztg., vol. 22, p. 104 (1903).-Kertesz, Ann. Mus. Hung., vol. 1, p. 569 (1903).

Front black, yellow anteriorly, face and cheeks whitish, antennae and palpi yellow. Thorax and abdomen shining black. Legs yellow, tarsi and middle of hind tibiae brown. Wings dark on apical half and between end of first vein, anal cell and posterior crossvein, only the base and a median crossband hyaline, third and fourth veins parallel, sections of fourth vein 1:7. Length $2.5-3 \mathrm{~mm}$.

Habitat.-Peru.

\section{CZERNYOLA BISETA Hendel.}

Czernyola biseta Hendel, Suppl. Ent. Berlin, vol. 2, p. 80 (1913).

Male.-Front and occiput black, face, mouthparts, and antennae yellow, arista evidently pubescent. Thorax and abdomen black, bristles reddish. Coxae and legs pale yellow, hind tibiae with preapical brown ring. Wings brownish, more intensive on middle of costal half, third and fourth veins parallel. Length $25 \mathrm{~mm}$.

Habitat.-Formosa.

38. CZERNYOLA CLARIPENNIS, new species.

Male.-Front rufous, piceous posteriorly, cheeks, mouthparts, and antennae whitish yellow, arista finely pubescent, three times the antennal length, vibrissa long and curved, two buccal setae half the length of the vibrissa, head bristles yellowish and strong, four frontoorbitals. Notum blackish, pleurae pale yellow the metapleurae black, two dorsocentrals, the anterior one weak. Abdomen blackish except base and venter yellow, hypopygium elongate. Legs uniformly whitish yellow. Wings nearly hyaline, sections of costa $5.5: 1.3: 1$, of fourth vein $1.6: 1: 4.5$, of evanescent fifth vein $1.5: 1$, third and fourth veins nearly parallel; halteres whitish. Length $3 \mathrm{~mm}$.

Holotype.-La Suiza de Turrialba, Costa Rica, Pablo Schild, collector, in Melander collection.

39. CZERNYOLA FASCIPENNIS, new species.

(Fig. 13.)

Female.-Front black, face and narrow cheeks cinereous black, antennae yellow, brownish at apex, arista finely but evidently pubescent, three times the antenna, one vibrissa, five uniform short buccal 
hairs, three fronto-orbitals. Thorax shining black, two dorsocentrals. Abdomen blackish brown, except at base and ovipositor. Front coxae, anterior femora except knees, apical two-thirds of hind femora and hind tibiae black, femora not fimbriate. Wings infumated, base and a transverse band extending over the posterior crossvein hyaline, sections of costa $5: 1.5: 1$, of fourth vein $2: 1: 4.5$, of fifth vein $1.5: 1$; halteres white. Length $3 \mathrm{~mm}$.

Holotype-La Suiza de Turrialba, Costa Rica (Pablo Schild), Melander collection. This may prove to be the unknown female of C. basalis.

40. CZERNYOLA TRANSVERSA Czerny.

Craspedochaeta transversa Czennì, Wien. ent. Ztg., vol. 22, p. 103 (1903).

Front reddish, darker above, face and cheeks whitish; antennae yellow, somewhat brownish apically, palpi yellow. Thorax reddish, with a median black stripe and a transverse stripe before the wings extending on pleurae to sternopleura, scutellum and metanotum black; bristles reddish, two dorsocentrals. Abdomen black. Legs reddish, coxae and base of femora paler. Wings brown on apical half and about crossveins, sections of fourth vein $1: 7$, third and fourth veins convergent. $3-3.5 \mathrm{~mm}$.

Habitat.-Peru.

\section{Genus HENDELIA Czerny.}

Hendelia Czerny, Wien. ent. Ztg., vol. 22, p. 83 (1903).

Front broad, the antennae distant, cheeks deep, arista thickened and thickly plumose; lunule covered; two reclinate fronto-orbitals, cruciate bristles present but small, no postverticals, ocellars distinct, prothoracic vestigial, one presutural and two postsutural dorsocentrals, no prescutellars, six scutellars, preapicals absent; crossveins approximate.

Genotype.-H. beckeri Czerny.

41. HENDELIA BECKERI Czerny.

Hendelia beckeri Czenny, Wien. ent. Ztg., vol. 22, p. 84, pl. 2, figs. 1-3 (1903).

Male.-Front yellowish, face, cheeks and palpi whitish, vibrissa long and strong, vibrissal angle of face rectangular; antennae lengthened, third joint brownish above, the black arista but little longer than antenna. Thorax reddish with three piceous vittae, upper pleurae piceous. Abdomen blackish. Legs yellowish, front tarsi flattened and black. Wings with apical spot, crossveins clouded, third and fourth veins convergent.

Female.-Face marked with black, vibrissa smaller, palpi large, blackened.

Habitat.-Austria. 


\section{Genus HETEROMERINGIA Czerny.}

Heteromeringia Czerny, Wien. ent. Ztg., vol. 22, p. 72 (1903).-Kertesz, Ann. Mus. Nat. Hung., vol. 1, p. 567 (1903).-Johnson, Psyche, vol. 20, p. 98 (1913).-Malloch, Proc. Ent. Soc. Wash., vol. 20, p. 7 (1918).

Lunule covered; three fronto-orbitals, the front pair convergent, no cruciates, postverticals present, ocellars distinct, no prothoracic, two posterior dorsocentrals, no prescutellars, apical scutellars convergent, no preapicals; crossveins approximate.

Genotype.- $H$. nigrimana Loew, the single original species.

The inclusion of Williston's West Indian species, H. valida and lumbalis, which have a preapical bristle on the middle tibiae, made this genus poorly defined. Moreover, these species have the neuration different from Heteromeringia, the crossveins being more widely spaced. The removal of the disturbing species to Sobarocephala leaves the genus Heteromeringia as clearly cut as the others of this family.

KEY TO THE SPECIES OF HETEROMERINGIA.

1. Wings with subbasal and apical clouding and central paler fascia; foremost buccal hair vibrissa-like; arista loosely pubescent or short-plumose.............

Wings uniformly darkened or with apical cloud; one vibrissa; arista closely



2. Legs wholly yellow, the middle tibiae sometimes with extremities brownish and front tarsi sometimes dusky. (West Indies, Fla.).......... flavipes Williston.

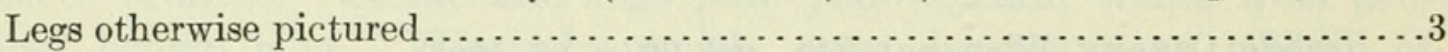

3. Hind femora and tibiae tipped with dark ring; apical cloud entirely beyond end of fifth vein; lower pleurae yellow. (N. Car.)............ annulipes Johnson.

Front tarsi and hind tibiae, and in female front tibiae also, black; apical cloud occupying nearly distal half of wing; pleurae wholly black; anterior half of male front opaque, pruinose when viewed from before. (Peru; C. Amer.)

czernyi $\mathrm{K}$

4. Front legs except coxa and sometimes base of femur black................. Anterior femora and middle tibiae black, rest of legs yellow; wings dark except at base; head black. (Peru)......................... nigrifrons Kertesz.

5. Halteres blackish; posterior legs yellow, only their coxae dark at base; cheeks mostly yellow. (Eur.)........................... nigrimana Loew.

Halteres white; posterior legs variable, usually yellow in Eastern United States specimens, sometimes femora and sometimes tibiae more or less darkened;

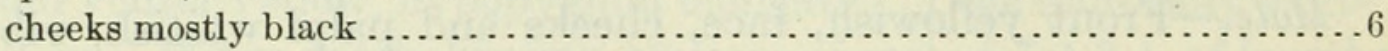

6. Wings with an apical cloud especially pronounced along costa; opaque anterior part of male front leaving a cordate smooth spot surrounding ocelli. (nitida

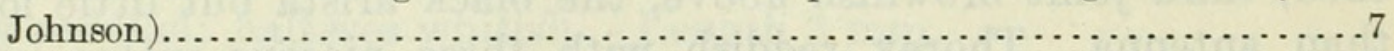

Wings dark except costal portion of base; opacity of male front restricted to anterior portion; distal third (male) or less (female) of hind femora and the hind tibiae black. (Costa Rica)........................ fumipennis, new species.

7. Posterior legs nearly or wholly yellow; front black; male palpi yellow, female palpi black with yellow tip. (Eastern U. S.)............... nitida Johnson, s. str.

Posterior femora and tibiae more or less blackened; male front reddish above antennae; palpi black except whitish tip. (U. S.)

nitida, form nigripes, new variety. 
Heteromeringia annulipes Johnson, Psyche, vol 20, p. 99 (1913).-Malloch, Proc. Ent. Soc. Wash., vol. 20, p. 8 (1918).

"Face and cheeks white, lower part of the front and orbits yellow; upper part of the front, the vertex and occiput black, palpi and antennae yellow, apical half of the third joint and arista dark brown. Thorax, upper half of the pleura, scutellum, metanotum, and abdomen, shining black; lower half of the pleura, legs and halteres yellowish white; tip of the posterior femora and tibiae annulated with dark brown. Wings hyaline, apical third, and a small area at the anterior crossvein, and end of the discal cell, slightly clouded with smoky black. Length $3 \mathrm{~mm}$."

Habitat.- The only record is the holotype specimen from Murfreesboro, N. Car. Type in collection of C. W. Johnson.

\section{HETEROMERINGIA CZERNYI Kertesz.}

(Fig. 20.)

Heteromeringia czernyi Kertesz, Ann. Mus. Hung., vol. 1, p. 568 (1903).

Front and occiput, thorax and abdomen black, face, cheeks, antennae, and mouthparts yellowish, arista finely short-plumose, front buccal hair nearly as large as vibrissa; anterior half of male front opaque, appearing white pruinose when viewed from before, front of female shining black. Legs mostly yellowish, front tibiae and tarsi and hind tibiae black, middle tibiae brownish, anterior femora of male with rows of strong flexor setae, scarcely developed in female, front tibiae of male less saturate black than of female. Wings infumated, base and central fascia pale, third and fourth veins parallel, sections of fourth vein $2.5: 1: 6$. Length $3-4.2 \mathrm{~mm}$.

Distribution.-The species was originally described from Peru. We have fifteen males and twelve females from San Mateo, Costa Rica (P. Schild) and Cabima, Panama (A. Busck). The species is doubtfully distinct from $H$. flavipes, differing only in the darker legs and front.

\section{HETEROMERINGIA FLAVIPES Williston.}

(Fig. 18.)

Heteroneura flavipes Williston, Trans. Ent. Soc. Lond., 1896, p. 387, pl. 13, fig. 135 (1896).-Czerny, Wien. ent. Ztg., vol. 22, p. 101 (1903).-Williston, Manual Dipt., p. 319 (1908).

Clusiodes flavipes Malloch, Proc. Ent. Soc. Wash., vol. 20, p. 6 (1918).

Front brown, red below, the orbits more yellowish, face, cheeks, mouthparts, and antennae yellow, the third joint brownish, arista finely pubescent. Thorax and abdomen black. Legs light yellow, flexor setae of anterior femora of male strong. Wings brownish, the base and central fascia clear, third and fourth veins parallel, sections of fourth vein $2.3: 1: 5$. Length $3 \mathrm{~mm}$. 
From a cotype specimen from St. Vincent in the collection of Cornell University. Johnson has recorded the occurrence of the species in Florida (Florida List). The National Museum has a specimen from Chinandega, Nicaragua, collected by C. F. Baker. After an examination of a cotype specimen Malloch located the species in Clusiodes, but Williston stated in his Manual that the cruciate bristles are lacking, as they are also in the present specimen.

45. HETEROMERINGIA FUMIPENNIS, new species.

(Fig. 19.)

Head black, face brown, proboscis and distal half of palpi, and antennae except apex yellow, arista closely pubescent, three times as long as antenna, the third antennal joint orbicular; cheeks onesixth eye-height, buccal hairs uniform; bristles black. Thorax and abdomen black, notum sericeous, notal hairs brown, pleurae and humeri polished, abdominal hairs black. Legs yellow except the distal two-fifths of front and hind femora, all of front and hind tibiae and the front tarsi which parts are black, posterior coxae mostly piceous. Wings infumated except costal portion of base, veins blackish, the second vein proximally yellow, costal sections proportioned $5: 1.6: 1$, fourth vein $2: 1: 6$, fifth vein $1.3: 1$, third and fourth veins nearly parallel; halteres entirely white. Length $3.5 \mathrm{~mm}$.

Habitat.-Costa Rica. Type male and six paratypes, Turrialba, collected by Pablo Schild, Melander collection. A paratype in possession of National Museum from same collector, Cat. No. 26266 U. S. N. M. A male in collection of American Entomological Society collected by P. P. Calvert at Juan Vinas.

\section{HETÈROMERINGIA NIGRIFRONS Kertesz.}

Heteromeringia nigrifrons Kentesz, Ann. Mus. Hung., vol. 1, p. 568 (1903).

Black, the orbits narrowly, antennae except apex, and tip of palpi yellowish; arista pubescent, buccal hairs short; legs reddish, femora and anterior tibiae largely black, the knees paler; wings infumated, the base yellowish, third and fourth veins parallel, sections of fourth vein $1: 5$; length $4.3 \mathrm{~mm}$.

Habitat.-Peru.

\section{HETEROMERINGIA NIGRIMANA Loew.}

Heteroneura nigrimana LoEw, Berl. ent. Zts., vol. 8, p. 338 (1864).

Heteromeringia nigrimana Czenny, Wien. ent. Ztg., vol. 22, p. 73, pl. 3 figs. 1 , 2 ; pl. 1, figs. 7,8 (1903)

Black, face, cheeks, mouthparts, antennae except tip, and most of legs yellow; arista short-pubescent; front legs with distal half of femur, most of tibia and all of tarsus black; wings with apical cloud, 
ART. 11.

third and fourth veins somewhat convergent, sections of fourth vein $1: 5$; halteres blackish; length $3.5 \mathrm{~mm}$.

Habitat.-Germany.

\section{HETEROMERINGIA NITIDA Johnson.}

Heteromeringia nitida Johnson, Psyche, vol. 20, p. 99 (1913).-Malloch, Proc. Ent. Soc. Wash., vol. 20, p. 8 (1918).

Male.-Black, the face, sometimes front part of cheeks, antennae except tip, palpi, coxae, basal half of front femora, and posterior legs yellow, sometimes extremities of hind tibiae brownish, knob of halteres white. Front largely opaque: arista short-pubescent. Wings infumated, strongly so along distal half of costal area, tip and about crossveins. $3 \mathrm{~mm}$.

Female.-Front not opaque; palpi black except yellow tip.

Distribution.-Originally described from New Jersey, where in the New Jersey List it had previously been enumerated as Heteroneura pictipes. Malloch records its occurrence in Illinois. The types are in the collection of C. W. Johnson. We have reviewed specimens from the National Museum from Dead Run, Va. (Shannon), Falls Church, Va. (Banks); Chesapeake Beach, Md. (Knab), Bladensburg, Md. (Shannon), Rock Run, Md. (Shannon), and Plummer Island, Md. (Barber).

Form nigripes, new variety (fig. 17). Middle and hind femora black except extremities; palpi of both sexes black except whitish tip; front of male reddish toward antennae.

William's, Ariz. (Barber), Mount Lemon, Ariz. (Shannon); Las Vegas, N. Mex. (Barber), Mathias Point, Va. (Shannon) and Westville, N. J., the last bearing Coquillett's identification label as Heteroneura pictipes Zetterstedt. The type, from Las Vegas, is Cat. No. 26296 U.S.N.M.

\section{Genus PARACLUSIA Czerny.}

Paraclusia Czerny, Wien. ent. Ztg., vol. 22, p. 90 (1903).

Foremost fronto-orbitals convergent, cruciates present, postverticals small, ocellars developed, prothoracic present, two postsutural dorsocentrals, prescutellars present, apical scutellars diverging, preapical very small, front coxae with one interior and three exterior bristles; crossveins distant.

Genotype.-The following and only species.

49. Paraclusia tigrina Fallén.

Helomyza tigrina FALLÉn, Heteromyz., p. 4 (1820).

Heteromyza trigrina Zettenstedt, Dipt. Sc., vol. 6, p. 2466 (1847).

Clusia tigrina Мıк, Ent. Nachr., vol. 23, p. 133 (1897).

Paraclusia tigrina Czenny, Wien. ent. Ztg., vol. 22, p. 90 (1903).

Heteroneura decora Loww, Wien. ent Monats., vol. 7, p. 39 (1863); Berl. ent.Ztg., vol. 8 , p. 337 (1864). 
Stomphastica decora Verral, Ent. Monthly Mag., vol. 30, p. 144 (1894).

Clusia decora Mrк, Ent. Nachr., vol. 23, p. 133 (1897) Wien. ent. Ztg., vol. 7, p. 167 (1898)

Clusia miki Handurnsch, Verh. z. b. Ges. Wien, vol. 34, p. 137, pl. 5. fig. 9 (1884).

Pholeogeton setiger Schiner, in litt., see Czerny, Wien. ent. Ztg., vol. 22 p. 91 (1903).

Front yellowish, opaque, face, cheeks and palpi pale yellow, antennae testaceous, brown at base of the pubescent arista, vibrissa strong, anterior two or three buccal hairs stronger than the others. Body testaceous, sometimes brownish marks on notum, pleurae and abdomen. Legs yellow. Wings with brownish clouds below end of first vein, about posterior crossvein and at apex, third and fourth veins diverging, sections of fourth vein $1: 1.3$. 6-7.5 mm.

Distribution.-Europe, Sweden to Southern Austria.

\section{Genus ALLOCLUSIA Hendel.}

Alloclusia Hendel, Deut. ent. Zts., 1917, p. 36 (1917).

Heterochroa Schiner, preoc., Novara Dipt., p. 236 (1868).

Peratochaetus Rondani, not 1856, which is Clusia Haliday; Arch. di Canestrini, p. 43 (1863); Bull. Ent. Soc. Ital., vol. 6, p. 8 (1874).-Czenny, Wien. ent. Ztg., vol. 22 , p. 92 (1903).

Four fronto-orbitals, the foremost convergent, no cruciates, ocellars and postverticals long, prothoracic well developed, one presutural and two postsutural dorsocentrals, four supra-alars, prescutellars long, a row of mesopleural bristles, the upper two longest, preapicals present; hypopygium robust; crossveins distant.

Genotype.-Peratochaetus philippii Rondani.

KEY TO THE SPECIES OF ALLOCLUSIA.

Posterior crossvein surrounded by a brown spot, three rounded hyaline spots in apical half and another large clear spot around anterior crossvein. (Chile)

philippii Rondani.

Whitish spots around both crossveins and several invading the cells. (Chile)

pictipennis Wulp.

\section{ALLOCLUSIA PHILIPPII Rondani.}

Peratochaetus philippii Rondani, Arch. di Canestrini, p. 43 (1863).-Czerny, Wien. ent. Ztg., vol. 22, p. 94, pl. 2, figs. 3, 5 (1903).

Heterochroa picta Schiner, Novara Dipt., p. 236 (1868).-Wulp, Notes Leyden Mus., vol. 4, p. 91, pl. 2, figs. 14, 15 (1882).-Handlirsch, Verh. z. b. Ges. Wien, vol. 34, p. 141, pl. 5, fig. 11 (1885).

Testaceous, front with median brown line, face, cheeks, mouthparts and antennae yellow, arista apical pubescent, buccal hairs small. Notum with two or three brown vittae, the lateral ones reaching sides of scutellum, metathorax brown, pleurae brown vittate above and on upper sternopleura. Abdominal segments marked with brown fasciae, hypopygium yellow with brown tip. Legs yellow. Wings infumated more intensely along costa, at end of third vein and along fourth vein, and with two hyaline fasciae and apical 
spot, the proximal fascia between end of first vein and anterior crossvein, the distal one consisting of three spots. $6 \mathrm{~mm}$.

Habitat.-Chile.

\section{ALLOCLUSIA PICTIPENNIS Wulp.}

Heterochroa pictipennis WulP, Notes Leyden Mus., vol. 4, p. 91, pl. 2, fig. 16 (1882).

Peratochaetus pictipennis Czerny, Wien. ent. Ztg., rol. 22, p. 96 (1903).

Ochraceous, front with median brown line, mesonotum bivittate, the stripes continuing on sides of scutellum, pleurae with upper and sternopleural vittae, abdominal segments in part brown, femora with preapical brown ring. Wings with brown and hyaline markings the clear spots located about both crossveins, in center of submarginal and first posterior cells, in second posterior cell, and a double spot at tip. $5 \mathrm{~mm}$.

Habitat.-Chile.

\section{Genus PHYLLOCLUSIA Hendel.}

Phylloclusia Hendel, Suppl. Ent. Berl., vol. 2, p. 78 (1913).

Three fronto-orbitals, the foremost proclinate, no cruciates, postverticals and ocellars long, prothoracic strong, three postsutural dorsocentrals, the front one small, prescutellars absent, one presutural, four scutellars, preapical absent; arista compressed; crossveins distant.

Genotype.-The original single species, P. steleocera Hendel.

\section{PHylloclusia STEleocera Hendel.}

Phylloclusia steleocera Hendel, Suppl. Ent. Berl., vol. 2, p. 78 (1913).

Reddish species with red bristles, thorax with several blackish lines, abdomen with several spots, legs reddish, wings brownish especially along costa; cheeks very narrow, one vibrissa. $6 \mathrm{~mm}$.

Habitat.-Formosa. Types in the German Entomological Museum.

\section{Genus SOBAROCEPHALA Czerny.}

Sobarocephala Czerny, Wien. ent. Ztg., vol. 22, p. 85 (1903).

Meriza Kertesz, Ann. Mus. Hung., vol. 1, p. 571 (1903).

Monorrhexa Kentesz, Ann. Mus. Hung., vol. 1, p. 572 (1903).

Lunule covered; three fronto-orbitals, the foremost pair convergent, cruciates absent, postverticals present, ocellars short, prothoracic vestigial, two posterior dorsocentrals, a pair of small prescutellar setae usually developed, apical scutellars convergent, usually two small lateral scutellars, preapical well developed on middle tibiae; crossveins relatively distant, the sections of the fourth vein usually ranging between $1: 3.5$ and $1: 2$.

Genotype.-S. rübsaameni Czerny. Erroneously this species was described as lacking preapical bristles on the middle tibiae. Thus 
mislead, Kertesz erected the genera Meriza and Monorrhexa for those species possessing preapicals. Monorrhexa was proposed for a species lacking prescutellars and having but four scutellars, and Meriza for the species having prescutellar setae and six scutellars. These characters are too inconstant to have generic value. Sobarocephala is apparently the dominant neotropical genus.

KEY TO THE SPECIES OF SOBAROCEPHALA. ${ }^{1}$

1. Wings with a large dark isolated spot around anterior crossvein $\ldots \ldots \ldots \ldots \ldots .2$ Wings with apical spot or extended clouding or uniformly subhyaline, butwith no special mark around anterior crossvein............................

2. Front less than one-third width of head; thorax with large posthumeral and supraalar spots, sctutellum black; wings with broad apical cloud, the cloud over the anterior crossvein connected with the cloud over the posterior cross-

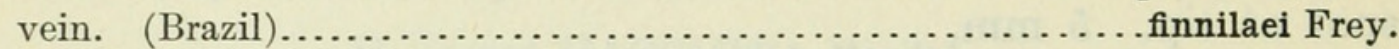

Front one-third the width of the head; thorax with black supraalar and usually without posthumeral spots, scutellum largely or wholly yellow; wings with apical cloudings at ends of veins, the clouds over the crossveins disconnected. (Peru; C. Amer.)................................ rubsaameni Czerny.

3. Arista densely bushy plumose; apex of wing and posterior crossvein blackish ....4 Arista loosely plumose or pubescent, at most bushy on basal half; apical infumation of wing extended or absent; posterior crossvein not markedly clouded; male lamellae usually rounded; thorax scarcely spotted or the spots large...5

4. Notum and pleurae marked with several black streaks; hind femora centrally and middle femora at extremities black, tarsi pale; a distinct cloud over posterior crossvein; lamellae long and ham-shaped. (Costa Rica).

variegata, new species.

Mesonotum marked with six spots, pleurae luteous; femora yellow, front tarsi black; cloud over posterior crossvein weak; lamellae minute. (Panama.)

plumata, new species.

Mesonotum marked with broad black stripe tapering in front and extending laterally as curved brown band, abdomen with central vitta; femora yellow, tibiae and tarsi brownish. (Surinam).................. pictipennis Kertesz .

5. Front decidedly narrowed above due to the bulging in of the eyes ..............6

Sides of front nearly parallel; humeri not contrastingly white; arista plumose . . . 7

6. Entirely yellowish, including bristles and legs; arista openly plumose. (Eastern

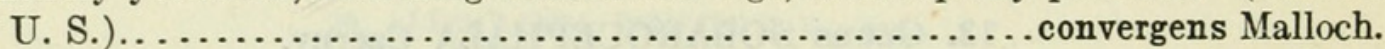

Thorax mottled, humeri contrastingly white; tibiae darker than remainder of legs; arista pubescent. (Costa Rica)................. humeralis, new species.

7. Mesonotum entirely black. . . . . . . . . . . . . .

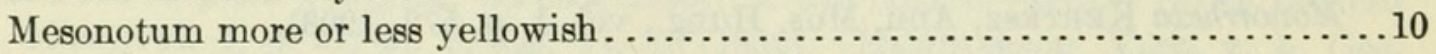

8. Pleurae concolorous with notum; sections of fourth vein 1:6. (W. Ind.)

concinna Williston.

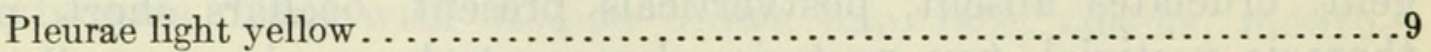

9. A brownish spot reaching down on pleura before wings; front yellow; sections of fourth vein 1:6. (W. Ind.) ..................... pleuralis Williston.

Pleurae entirely yellow; front largely black; sections of fourth vein 1:3. (Costa

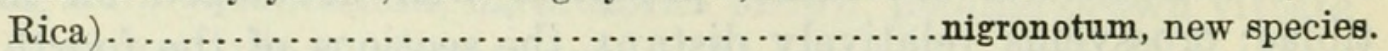

10. Mesonotum with blackish marks...............................

Mesonotum yellow, at most blackish in the scutellar region ${ }^{2} \ldots \ldots \ldots \ldots \ldots \ldots 21$

11. All femora centrally more or less blackish; meso- and metapleurae largely black. 12 Femora not annulate; pleurae entirely yellow, at most the metapleurae black...13 
12. Tibiae, tarsi, scutellum and face yellow; wings bifasciate. (Panama)

fascipennis, new species.

Tibiae, front tarsi, scutellum and face black; outer two-thirds of wings dark.

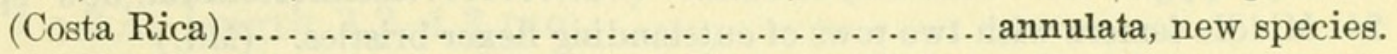

13. Lateral black marks of mesonotum extending over the humeri............. 14

Humeri yellow like the central anterior portion of the notum; hypopygium yellow . . . . . . . . . . . . . . . . . . . . . . . . . . . . . . . . .

14. Posterior half of mesonotum and the scutellum black, abdomen black; tibiae dark; prescutellars absent; wings infumated except at base ................. 15

Middle vitta of notum, metapleurae, scutellum and abdomen including hypopygium black; legs wholly yellow; prescutellars absent; wings uniformly yellowish; base of arista densely plumose (Costa Rica)....... plumatella, new species.

Mesonotum and scutellum yellow except for lateral stripes, abdomen mostly yellowish; tibiae yellow; prescutellar setae present; wings darkened along costa and tip. (Eastern U. S.) (if lateral stripe is bisected and marginal cell not dark see bivittata.). . . . . . . . . . . . . . . . . . . . . latifrons Loew.

15. Notum with black center stripe; second vein distinctly diverging from third

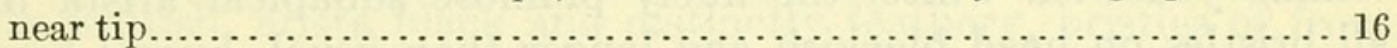

Notum uniformly black except for a central round yellow spot toward the front; second vein slightly diverging from third. (Costa Rica)

xanthomelana, new species.

16. Wings broad, twice as long as wide, costa strongly arched opposite posterior crossvein and spinulose, the second vein abbreviated, costal sections $2.5: 2: 1$, sections of fourth vein 1:2. (Costa Rica) ........... latipennis, new species.

Wings normal, more than twice as long as wide, second vein not shortened, the costal sections 4.5:1.5:1, sections of fourth vein 1:2.5. (Costa Rica)

liturata, new species.

17. Posterior portion of mesonotum black, apparently marked with three fused vittae which disappear in front, scutellum and metathorax black; only front tarsi brown. (Peru; Costa Rica) (if notum has broad black stripe tapering anteriorly and extending laterally as bowed brown band, see pictipennis Kertesz.)

dorsata Czerny.

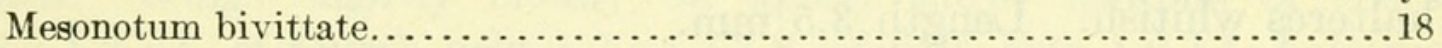

18. Wings with apical clouding; front tibiae and tarsi more or less brown; prescutellars present . . . . . . . . . . . . . . . . . . . 19

Wings uniformly hyaline; legs yellow; no prescutellars; scutellum brown.....20

19. Lateral mark of thorax obliquely interrupted by the suture, the anterior spot adjacent to the margin (sometimes absent), the posterior located between the supra-alar and dorsocentral bristles; scutellum laterally or wholly black. (Costa

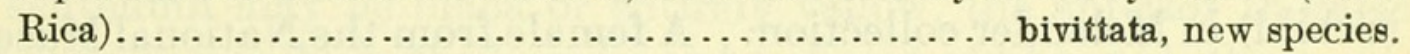

Lateral mark of thorax not extending in front of suture; scutellum black or yellow bistrigata Kertesz.

20. Yellow of sides of mesonotum extending behind suture. (West Ind.; C.



Lateral black marks of mesonotum extending in front of suture. (West Ind.) valida Williston.

21. Femora devoid of flexor combs of setae; a faint cloud at end of second vein; front tarsi alone somewhat dusky; body entirely yellow. (U. S.). flava, new species.

Underside of anterior femora furnished with a row of black or sometimes pale

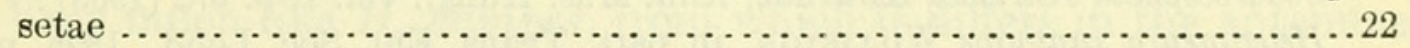

22. Mesosternum with long hairs; abdomen bristly with hairs; hypopygium longer than depth of abdomen; cheeks silvery pruinose when viewed from above.. 23

Mesosternum short-hairy but not setose; abdomen not markedly bristly; hypopygium small. ......................................... 24 
23. Valves of hypopygium very large, scoop-shaped, extending forward under abdomen. (Costa Rica)....................... hypopygialis, new species. Hypopygial valves hidden, circular. (Va.)........lachnosternum, new species.

24. Middle femora with two rows of outstanding flexor bristles. (Md.)

setipes, new species.

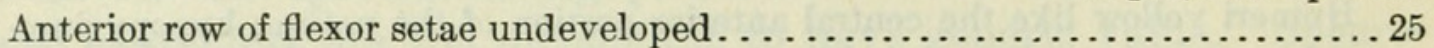

25. Mesonotum paler in middle than on the brownish sides; wings nearly hyaline.

(West Ind. ; Panama) ............................ lumbalis Williston.

Mesonotum ferruginous, at most the scutellar region darker; wings with vague apical clouding. (S. and C. Amer.)................. ferruginea Czerny.

53. SOBAROCEPHALA ANNULATA, new species.

(Fig. 34.)

Male.-Front pale yellowish, ocellar dot shining black, face and cheeks whitish, the bucca rimmed with black; mouthparts and antennae yellowish white, the finely plumose subapical arista black; all bristles on head blackish and longer than usual, buccal hairs all small. Thorax shining, variegated yellow and black, mesonotum with a broad shining central spot extending back to meet the black scutellum, metanotum brownish with a large black spot on either metapleura, mesopleurae largely black; posterior dorsocentral strong, two pairs of basal scutellar setae, notal hairs black. Abdomen black except at extreme base, hypopygium small. Legs yellowish with black bristles, the femora with central black annulus, posterior flexor bristles of front femora strong. Wings twice as long as wide, smoky on outer half, costa vanishing at third vein, costal ratio $3.5: 1.6: 1$, sections of fourth vein $1: 1: 2$, of fifth vein $3: 1$, second vein strongly diverging from third; calypteres pale with black edge and fringe; halteres whitish. Length $3.5 \mathrm{~mm}$.

Female.-Head luteous, a medial vitta sometimes extending along front and face, antennae deep yellow. Abdomen with last segment and ovipositor whitish. All tibiæ and front tarsi blackish. Length $4.5 \mathrm{~mm}$.

Types.-Seven males and five females, Turrialba, Costa Rica (Schild) in Melander collection. A female from the National Museum, Cat. No. 26267, U.S.N.M., collected by August Busck at Porto Bello, Panama, is considerably darker; the front and face are smudgy, the black spot of notum connects with the prealar pleural spot, and the femora are largely blackened.

\section{SOBAROCEPHALA BISTRIGATA Kertesz.}

-(Fig. 33.)

Sobarocephala bistrigata Kertesz, Ann. Mus. Hung., vol. 1, p. 572 (1903) .

Heteroneura xanthops Wilisston, in part, Trans. Ent. Soc. Lond., 1896, p. 386 (1896).-Czerny, in part, Wien. ent. Ztg., vol. 22, p. 100 (1903)

Ochraceous, posterior sides of notum black, scutellum, metapieurae and abdomen except base and apex black; legs yellow, the front 
tibiae and tarsi and hind tibiae brown; arista closely plumose; wings infumated on apical third and above fifth vein, sections of fourth vein $1: 3.5$; length $3.2-4.3 \mathrm{~mm}$.

Distribution.--Originally described from Peru. Specimens from Costa Rica, Jamaica, and St. Vincent, the last a cotype of Heteroneura xanthops Williston, have the scutellum and metathorax yellow, the antennae not brown at tip, the arista rather openly plumose, and the hind tibiae less evidently brown. There is some variation in size of hypopygium, the St. Vincent specimen having the hypopygium very robust.

55. SOBAROCEPHALA BIVITTATA, new species.

(Fig. 36.)

Front, face, antennae and mouthparts yellow, ocellar dot black, cheeks whitish, arista black and distinctly feathery, bristles of front brown, buccal hairs all small. The shining yellow mesonotum bivittate with black, each vitta obliquely interrupted behind the suture, the anterior spot reaching along notopleural suture from humeri to base of wing, the posterior stripe beginning near middle of notum and extending exteriorly to dorsocentral rows to include sides of the yellow scutellum; pleurae pale yellow, metanotum brownish, metapleurae brown; notal hairs and bristles black, two lateral scutellar setulae. Dorsum of abdomen with a large central oval black spot widest on fourth segment; hypopygium yellow, of medium size. Legs yellow, with blackish hairs; front tarsi dusky, flexor setae of posterior row of front femora nearly as long as femur-width and black. Wings slightly cloudy on apical third, sections of costa $4.3: 1.2: 1$, of fourth vein $1.2: 1: 3.8$, of fifth vein $1.6: 1$; halteres whitish. Length $3.5-4 \mathrm{~mm}$.

Types.-Seven specimens, Turrialba, Costa Rica, July (Pablo Schild) in Melander collection, and four in National Museum, Cat. No. 26268, U. S. N. M. The species is variable in extent of color, the scutellum may be black or entirely yellow, the anterior thoracic spot may encroach on the humeri or be almost obliterated, the metathorax may be wholly yellow. S. bistrigata and this species may ultimately prove to be geographic races of one widely distributed variable neotropical species.

56. SOBAROCEPHALA CONCINNA Williston.

Heteroneura concinna Williston, Trans. Ent. Soc. Lond., 1896, p. 387 (1896).Czerny, Wien. ent. Ztg., vol. 22, p. 101 (1903).

"Very much like $H$. flavipes, from which it differs in the antennae being wholly light yellow, in the wings being nearly uniformly blackish, except the immediate base, and especially in the presence of distinct preapical bristles on the middle and hind tibiae. It is also a little smaller." (Williston.) 
Habitat.-St. Vincent. Major E. E. Austen has furnished the following information regarding the male type in the British Museum: Cruciate bristles absent, postverticals present, middle tibiae with preapical, first vein bare, sections of fourth vein about $1.6: 1: 5.5$. The species thus finds its best location in Sobarocephala.

\section{SOBAROCEPHALA CONVERGENS Malloch.}

(Fig. 31.)

Heteromeringia convergens Malloch, Occ. Papers Bost. Soc. N. Hist., vol. 5, p. 50 (1922).

Heteromeringia flaviseta Malloch, Proc. Ent. Soc. Wash., vol. 20, p. 7 (1918).

Entirely yellowish, the bristles yellow, lower part of head and body and the humeri whitish; head robust, front narrowed above by the bulging in of the eyes, cheeks more than one-fourth the eyeheight; abdomen sometimes darkened toward tip; wings hyaline, apically with faint cloud about end of second vein; lamellae of hypopygium bluntly triangular, a little longer than wide; $4 \mathrm{~mm}$.

Recorded from Illinois, Indiana, Virginia, and Missouri. We have specimens from White Mountains, N. H., Plummer Island and Washington, D. C., Algonquin, Ill., southern Georgia. The species is readily distinct among those from the States in the peculiar shape of the eyes, whose anterior margins diverge strikingly from the level of the uppermost orbital bristle to their lowest point. Malloch described the larva and puparium in his earlier paper, and suggested the possible identity of the species with latifrons. In view of the different head structure the two species are undoubtedly distinct, a conclusion also evidently reached by Malloch when he bestowed a new specific name on this form.

\section{SOBAROCEPHALA DORSATA Czerny.}

(Fig. 38.)

Sobarocephala dorsata Czerny, Wien. ent. Ztg., vol. 22, p. 105 (1903).

Meriza dorsata Kertesz, Ann. Mus. Hung., vol. 1, p. 571 (1903).

Ochraceous, posterior part of mesonotum with a quadrate black spot which extends over scutellum and metathorax, sometimes also a supra-alar spot; abdomen largely black; front tarsi brownish; wings nearly hyaline, with a vague apical cloud; arista evidently plumose, face ochraceous, buccal hairs small, cephalic bristles typically yellowish, notal bristles brown, prescutellar setae present. Length, 3.5-3.9 mm.

Distribution.-Originally described from Peru. Specimens agreeing well with the description are before us from Costa Rica, collected by Pablo Schild. 
59. SOBAROCEPHALA FASCIPENNIS, new species.

(Fig. 29.)

Male.-Beautifully variegated in color, black, brown, yellow, and white, as follows: Upper occiput and front ochraceous, paler toward antennae; face, vibrissal angle of cheeks, lower occiput, mouth parts, and antennae flavous, cheeks blackish; mesonotum ochraceous before suture, the sides between the brown humeri and root of wing white, posterior two-thirds of notum dark castaneous, scutellum whitish, metathorax black, pleurae entirely blackish brown; base of abdomen yellowish, remainder black; coxae and posterior femora except knees blackish, remainder of legs pale yellow; halteres yellow; wings with two infumated cross-bands, one including apical fourth, the other extending between the crossveins, base and preapical portions subhyaline, costal veins yellow up to the apical cloud; arista black, bristles and hairs nearly concolorous with the integument, the reclinate front-orbitals and setae of front femora black. Arista longpubescent, buccal hairs small; front occupying less than one-third the head, longer than wide, its orbits nearly parallel; prescutellars relatively strong, only one lateral scutellar seta; front femora with double row of flexor setae; the black hypopygial valves shaped like an orange spoon; third vein ending at tip of wing, parallel with fourth; sections of costa $5.5: 1.4: 1$, of fourth vein $1: 1: 3$. Length $3 \mathrm{~mm}$. Holotype.-Alhaluelo, Panama, 12 March, 1912, August Busck, collector, U. S. National Museum, Cat. No. 26269, U.S.N.M.

\section{SOBAROCEPHALA FERRUGINEA Czerny.}

Sobarocephala ferruginea Czerny, Wien. ent. Ztg., vol. 22, p. 105 (1903).

Ochraceous, bristles concolorous, sometimes scutellum and posterior middle part of mesonotum brownish; arista evidently plumose; front tarsi brownish, front femora with flexor bristles; wings nearly hyaline, with a faint apical clouding; $3.5 \mathrm{~mm}$.

Habitat.-Peru. A few specimens from Costa Rica secured from Pablo Schild probably belong to this species. The hypopygium is small and yellow, the middle portion of the abdomen brownish. Possibly $S$. dorsata is the same species, since the relative intensity of dark color in the scutellar region is of doubtful specific value.

\section{SOBAROCEPHALA FINNILÄI Frey.}

Sobarocephala finniläi Frey, Ofvers. Vet. Soc., vol. 60, p. 32 (1919).

Head, including antennae and mouthparts ochraceous, arista plumose. Thorax ochraceous, with two broad black vittae which are triangularly excised along outer side at suture, scutellum and metathorax black. Abdomen black except at base. Legs entirely yellow. Wings cinereous, costal cell and base yellow, with three 
broad infumations, located between first vein and anterior crossvein surrounding posterior crossvein, and at apex, the last rectangularly excised within; sections of fourth vein $1: 3$. Length $5 \mathrm{~mm}$.

Habitat.-Brazil.

62. SOBAROCEPHALA FLAVA, new species

(Fig. 22.)

Female.-Head ochraceous, ocellar dot black, cheeks and mouthparts flavous, third antennal joint reniform, blackish, with finely plumose arista; head bristles black and strong, four or five long delicate buccal hairs. Thorax ochraceous, notal hairs close fine and dusky; prescutellar setae present, two lateral setae on scutellum, sternal hairs not conspicuous. Abdomen reddish yellow, darker posteriorly. Legs yellow, the front tarsi brown, tibial spurs black, flexor setae of front femora vestigial. Wings hyaline, lightly infumated about apical end of second vein, costal ratio $4.5: 1.2: 1$, fourth vein $1.2: 1: 3$, fifth vein $1.5: 1$; halteres yellowish; calypteres yellowish with blackish border and fringe. Length $3 \mathrm{~mm}$.

Puparium.-Reddish brown, trilobed at cephalic end, transversely striated, posterior end irregularly rugose, tipped with two simple hooks, anal opening surrounded by a black nearly semicircular plate, venter of last segment sharply margined behind. Length $3.5 \mathrm{~mm}$.

Types.-Reared by Shannon from puparia found at Dead Run, Fairfax County, Virginia, in what was thought to be a maple log, the adults issuing April 15. Type in National Museum, Cat. No. 26270, U. S. N. M. Paratypes from Plummer Island, Md., Falls Church. Va., and Opelousas, La. All the specimens are females.

63. SOBAROCEPHALA FLAVISETA Johnson.

Heteromeringia flaviseta JoHnson, Psyche, vol. 20, p. 99 (1913).

Yellow, the face, cheeks, lower occiput, humeri, pleurae, coxae and legs whitish; head bristles yellowish; antennae fulvous yellow, arista blackish; posterior abdominal segments with brownish marks; wings yellowish hyaline, apical third slightly clouded, especially near veins; $4 \mathrm{~mm}$.

Habitat.-New Jersey. One of the two known specimens was recorded in the New Jersey list under the name of Clusia flava. The species discussed by Malloch as flaviseta is convergens.

\section{SOBAROCEPHALA HUMERALIS, new species.}

(Fig. 25.)

Female.-Front and center of face brownish yellow, the ocellar, dot blackish, occiput luteous, cheeks and facial orbits pale yellow with a conspicuous dark spot below the eye; antennae flavous, 
arista nearly three times the antennal length and pubescent; front decidedly narrowed above due to the bulging in of the eyes; bristles small, brown, buccal hairs short. Mesonotum mostly black, a central vitta and sutural spot yellowish, humeri and sides of mesonotum in front of suture contrastingly white, scutellum whitish, metanotum brown; pleurae shining yellow with two black spots, one directly under humeri, the other behind the front coxae, metapleurae black; presuturals present, one lateral scutellar seta located well up on the disk, thoracic bristles brown. Abdomen black except at yellowish base. Legs yellow except front tarsi and all tibiae which are blackish; flexor femoral bristles undeveloped, only three in posterior row of front femora near knee. Wings nearly hyaline, a vague clouding at apex and in distal half of discal cell, first and second veins yellow, others black except at root; costal ratio $5: 1.5: 1$, fourth vein $1: 1$ : 2.5. fifth vein $2.5: 1$; halteres pale yellow. Length $4 \mathrm{~mm}$.

Type.-La Suiza de Turrialba, Costa Rica, collected during August, 1921, by Pablo Schild; in Melander collection.

Variations.-A female in the National Museum, Cat. No. 26271, U.S.N.M., from the same collector represents an extreme pale variation. The genal spot is luteous, the black of the mesonotum is reduced to a prescutellar spot medially excised in front and another in front of the wings, the pleurae and metathorax are immaculate yellow, the abdomen black only on the middle tergites, and the tibiae have a faint brown ring below the knee. Another female, collected by Dr. P. P. Calvert at Juan Vinas, Costa Rica, in the collection of the American Entomological Society, represents the other color extreme. The upper sides of the occiput are black, the notum and pleurae are wholly black except for the humeral-lateral white mark and the white scutellum, and the clouding of the wings is more evident. Structurally the three specimens agree.

65. SOBAROCEPHALA HYPOPYGIALIS, new species.

(Fig. 41.)

Male.-Front shining yellow, more opaque and luteous above antennae, ocellar spot black, face and cheeks white, the genae silky; mouthparts and antennae yellowish, the latter brown above the black plumose arista; bristles of head long and brown, four long buccal hairs. Notum shining ochraceous with two narrow parallel very faint brownish dorsocentral stripes reaching from center of mesonotum to tip of scutellum, notal hairs and bristles black, prescutellars lacking, two lateral scutellar setae; pleurae pale yellow, mesosternal hairs long. Abdomen black-bristly, yellowish brown, hypopygium yellowish and unusually large, the valves very large and scoop-shaped extending forward under the abdomen and almost reaching the base., Legs yellowish, hairs black, front tarsi brownish, front femora with 
nine long setae in posterior flexor row, middle femora with twelve moderate setae in posterior row and about four oblique setae in anterior row toward knee. Wings almost uniformly hyaline, costal ratio $4.5: 1.2: 1$, fourth vein $1: 1: 2.6$, fifth vein $2: 1$. Length $3 \mathrm{~mm}$.

Types.-Two males, La Suiza de Turrialba, Costa Rica, Pablo Schild collector, in Melander collection. Several females from Mr. Schild may be the same species. They all have weaker femoral setae, some have darkened scutellum, none has the brown spot at end of antennae nor the faint dorsal vittae, and one has shorter plumosity of the arista.

66. SOBAROCEPHALA LACHNOSTERNUM, new species.

(Fig. 21.)

Front shining ochraceous, opaque luteous above the antennae, ocellar dot black, face and mouthparts yellow, genae silvery pruinose, a brownish line below each antenna, extending on bucca; antennae luteous, arista short-plumose; head bristles brown, five delicate long buccal hairs. Thorax shining ochraceous, pleurae and coxae flavous, sometimes, especially in female, with lateral brownish marks behind the humeri, prescutellar setae sometimes absent, hairs of mesosternum and coxae long and conspicuous. Abdomen strongly setose, brownish in male, yellow with brown middle portion in female; hypopygium large and yellow, valves circular. Legs uniformly yellow except the brownish front tarsi, flexor setae of anterior femora strong and black. Wings nearly hyaline, costal ratio $5: 1.3: 1$, sections of fourth vein $1: 1: 3.3$, of fifth vein $1: 2.6$; halteres pale yellow. Length $3 \mathrm{~mm}$.

Puparium.-Reddish brown, closely and transversely striate, last segment irregularly rugose, posterior extremity with two hooks, each with basal prong on inner side, anal opening elliptical and surrounded by a black trapezoidal plate, no sharp margin at rear of last sternite. Length $5 \mathrm{~mm}$.

Types.-Ten specimens, Rosslyn and Dead Run, Va., bred by Shannon from larvae found in rotting wood. Type, Cat. No. 26272, U.S.N.M.

\section{SOBAROCEPHALA LATIFRONS Loew.}

(Fig. 32.)

Heteroneura latifrons Loew, Wien. ent. Monats., vol. 4, p. 83 (1860); Berl. ent. Zts., vol. 7, p. 207; Cent. 4, 93 (1863).-CzerNy, Wien. ent.Ztg., vol. 22, p. 99 (1903).

Heteromeringia latifrons Johnson, Psyche, vol. 20, p. 99 (1913).-Malloch, Proc. Ent. Soc. Wash., vol. 20, p. 8 (1918).

Testaceous, lower part of head and thorax flavous; arista black, two and one-half times length of antenna, relatively long-plumose, buccal hairs vestigial, bristles strong and black; cheeks one-sixth eye-height, front square. Sides of mesonotum including the humeri brown, metapleurae brown, two pairs of lateral setae on scutellum, 
prescutellar setae present. Abdomen yellowish, base and apex somewhat brown, ovipositor yellow. Legs yellow, middle tibiae with preapical bristle. Wings infumated along costa and tip, elsewhere cinereous, third vein curving back to end almost at wing-tip, costal sections $5: 1.2: 1$, fourth vein $1.2: 1: 4$; halteres yellow. Length $3.5 \mathrm{~mm}$.

Distribution.--Massachusetts, New Jersey, Pennsylvania, District of Columbia, Indiana, Illinois. Shannon has taken the species on Plummer Island, Md., and at Dead Run, Va.

The species is similar to flava, differing in the greater approximation of the crossveins, the more extended infumation of the wings, darker thoracic markings, and in the presence of setae along the anteroflexor edge of the front femora.

68. SOBAROCEPHALA LATIPENNIS, new species.

(Fig. 24.)

Male.-Front and center of face brown, cheeks yellow, antennae and mouthparts luteous, arista three and three-fourth times the length of the antenna, short-plumose, almost openly pubescent, cephalic bristles strong and black, four buccal hairs; head remarkably wide, front broader than eye. Mesonotum mostly black, a broad C-shaped yellow spot on each side enclosing the suture, scutellum black, metanotum brownish, pleurae whitish, metapleura black. Abdomen black except at yellowish base, hypopygium small, with yellowish valves. Legs yellow with exception of all tibiae and front tarsi which are blackish, about twelve pale setae in posterior row of front femora, only two prominent setae in posterior row of middle femora. Wings broad, only twice as long as wide, costa strongly arched and aciculate, second vein abbreviated and bent forward to end midway between tip and posterior crossvein, costal ratio $2.5: 2: 1$, fourth vein $1: 2.5$, fifth vein $3.5: 1$; outer half of wing strongly infumated, contrasting with hyaline basal half; halteres whitish. Length $3 \mathrm{~mm}$.

Type and two paratypes.-Turrialba, Costa Rica, Pablo Schild collector, in Melander collection. Paratype: Porto Bello, Panama, August Busck, in National Museum, Cat. No. 26273, U.S.N.M. A beautiful species allied to $S$. liturata but differing from all the species in its curious wing formation.

69. SOBAROCEPHALA LITURATA, new species.

(Fig. 42.)

Male.-Front and face brownish, facial orbits and cheeks white, the bucca rimmed with brown, mouthparts and antennae yellow, the black short-plumose arista three and a half times the antennal length, four short buccal hairs, cephalic bristles strong and black, 
ocellar bristles reaching half-way to antennae and equal to postverticals; front narrower than eye. Mesonotum brownish, on each side in front with an inverted $\mathrm{H}$-shaped yellow spot, scutellum black, metanotum brown, pleurae pale yellow, metapleura blackish; notal hairs and bristle black, prescutellars absent, one lateral scutellar seta located well up on disk, sternal hairs short and yellow. Abdomen blackish except at extreme base, hypopygium small, valves nearly square. Legs yellowish, posterior knees capped with brownish, front tibiae and front tarsi black, hind tibiae brownish before apex, hairs dark, though pale at base of femora, nine black setae in posterior flexor row of front femora, middle femora with four setae in front row near knee and eighteen setae in posterior row arranged the full length of the femur. Wings with apical three-fourths cloudy, gradually merging into the subhyaline base, costal ratio $4.5: 1.5: 1$, fourth vein $0.9: 1: 2.5$, fifth vein $2.25: 1$, second vein distinctly diverging from third at tip, but ending much nearer to tip of wing than to posterior crossvein; halteres white. Length $3 \mathrm{~mm}$.

Female.-Abdomen with last segment and ovipositor whitish; hind tibiae black.

Types.-Ten specimens, Turrialba, Costa Rica, secured from Pablo Schild, Melander collection. Paratype deposited in National Museum, Cat. No. 26274, U.S.N.M. Remarkably constant in structure and color.

70. SOBAROCEPHALA LUMBALIS Williston.

(Fig. 37.)

Heteroneura lumbalis Williston, Trans. Ent. Soc. Lond., 1896, 388 (1896).Czerny, Wien. ent. Ztg., vol. 22, p. 103 (1903).-Williston, Manual N. Am. Dipt., 3 ed., p. 319 (1908).

Heteromeringia lumbalis Malloch, Proc. Ent. Soc. Wash., vol. 20, p. 8 (1918).

Head, thorax, antennae, palpi, hypopygium, ovipositor, legs and halteres yellow, the posterior part of mesonotum and the scutellum brown, abdomen blackish, extreme base yellowish in female. Arista plumose, buccal hairs small, bristles strong and brown, no prescutellars, a single minute lateral scutellar hair. Hypopygial lamellae rounded elongate triangular. Preapical bristles of middle tibiae strong. Wings and veins yellowish, not clouded, sections of costa $4: 1.1: 1$, of fourth vein $1.1: 1: 3.5$, third vein ending almost at wing-tip. Length $2.5-3 \mathrm{~mm}$.

Distribution.-Described from cotype specimens from collection of Cornell University. Original locality, St. Vincent, West Indies. Recorded by Malloch from Grenada. The National Museum contains the species from Alhajuelo and Paraiso, Panama, collected by August Busck. 
71. SOBAROCEPHALA NIGRONOTUM, new species.

(Fig. 28.)

Male.-Front blackish brown, mouthparts, cheeks, and face whitish, the latter centrally grayish with the facial ridges brownish; antennae reddish yellow, arista black and finely short-plumose; head bristles reddish yellow. Notum entirely black, pleurae pale yellow, metapleura brownish; prescutellars scarcely larger than the black notal hairs, two small lateral scutellar setae. Abdomen blackish, hypopygium yellow, valves oblong twice as long as wide and crossing each other. Legs uniformly pale yellow, only the hind femora with slight duskiness before knee, no flexor femoral bristles. Wings uniformly and strongly infumated, veins blackish, costal ratio $4: 1.3 ; 1$, fourth vein $1: 1: 2.7$, fifth vein $1.5: 1$; halteres pale yellow. Length $3 \mathrm{~mm}$.

Female.-Front reddish with a black central stripe, face yellowish marked with a $\mathrm{W}$-shaped brown design, clypeus brownish, facial orbits and cheeks whitish, six long delicate buccal setae, mouthparts yellow. Last abdominal segment and ovipositor pale yellow. Front tarsi and all of the tibiae dark, the five setae on the postero-upper edge of front femora dark and stronger than in male. Length 3.75 $\mathrm{mm}$.

Types.-Two males and two females. La Suiza de Turrialba, Costa Rica (Pablo Schild), Melander collection. One of the paratypes deposited in National Museum, Cat. No. 26275, U.S.N.M.

\section{SOBAROCEPHALA PICTIPENNIS Kertesz.}

Monorrhexa pictipennis Kentesz, Ann. Mus. Hung., vol. 1, p. 573 (1903).

Reddish yellow, a little shining. Upper part of head yellowish gray, lower part concolorous but somewhat lighter, ocellar spot black. Mesonotum with a broad black clear-cut vitta tapering in front and anteriorly sending a blackish brown bowed band to each side margin; base of scutellum with a brown line which continues toward the apex in a curved angle. Abdomen reddish but marked with a broad black vitta which ends on the fifth segment. Tibiae and tarsi infuscated. Wings with yellowish tinge, apical third more or less brown, a paler brown mark over the posterior crossvein which in front forms a semicircular spot in the first posterior cell; hind margin clear brown; halteres yellow. Length $5.5 \mathrm{~mm}$.

Habitat.-Surinam, South America.

\section{SOBAROCEPHala PLEURALIS Williston.}

Heteroneura pleuralis Williston, Trans. Ent. Soc. Lond., 1896, p. 387 (1896).Czerny, Wien. ent. Ztg., vol. 22, p. 102 (1903).

Head, pleurae and legs light yellow, notum and a prealar pleural spot dark brown, abdomen black except immediate base. Wings 
smoky hyaline, the apical third and a spot over crossveins brown, penultimate section of fourth vein about one-third the last section of fifth vein and only a little longer than posterior crossvein. Arista yellow at the base, very finely pubescent. Length $2.5 \mathrm{~mm}$.

Habitat.-St. Vincent. Major E. E. Austen has courteously furnished the following additional information regarding the holotype in the British Museum: cruciates absent, postverticals present, one dorsocentral, middle tibiae with preapical, first vein bare, sections of fourth vein about $3.5: 1: 6.5$. Notwithstanding the approximation of the crossveins the chaetotaxy places the species best in the genus Sobarocephala.

74. SOBAROCEPHALA PLUMATA, new species.

(Fig. 35)

Female.-Front and occiput luteous, face and cheeks pale, mouthparts and antennae reddish yellow, the third antennal joint with a dusky stripe on outer side at base of arista, the arista black and densely short-plumose, twice the length of antennae, ocellar bristles microscopic, cephalic bristles yellowish, four very delicate buccal hairs. Thorax reddish yellow, with six blackish spots arranged in pairs, one at lateral margin anterior to wing, one much smaller on the same transverse line just outside the dorsocentral row, and a third pair across the suture in front of the second pair; scutellum and metanotum black, pleurae luteous; bristles yellowish, prescutellars scarcely differentiated. Legs yellowish, the front tarsi and adjoining half of tibiae dusky. Wings hyaline, cloudy on apical third and with a slight clouding over posterior crossvein, costal ratio 4: 1.2, fourth vein 1.4: $1: 3.2$, fifth vein $2: 1$; halteres whitish; calypteres yellowish with brownish border. Length $3.5 \mathrm{~mm}$.

Holotype.-Alhajuelo, Canal Zone, Panama, collected by August Busck, in National Museum, Cat. No. 26276, U.S.N.M.

\section{SOBAROCEPHALA PLUMATElla, new species.}

(Fig. 39.)

Male.-Occiput and front ochraceous, face, cheeks, antennae and mouthparts yellow, arista black, closely plumose on basal two-fifths, remainder openly plumose, cephalic bristles ferruginous. Mesonotum marked with a black vitta between the dorsocentral bristles, tapering

point behind the neck, laterally blackish, between these stripes ivittate with chraceous; scutellum black, metanotum and pleurae pale yellow, the metapleura black; thoracic bristles blackish. Abdomen black except the first segment, the sternites and the small quadrate lamellae, a l of which parts are yellowish. Legs entirely yellowish, flexor fringe of front femora with uniform short setae. Wings subhyaline, gradually darker to tip, costal sections $3.6: 1$, of 
fourth vein 1.2:1:3.6, of fifth vein $1.5: 1$; halteres pale yellow. Length $3.4 \mathrm{~mm}$.

Holotype.-La Suiza de Turrialba, Costa Rica, November, 1922 (Pablo Schild), in Melander collection.

76. SOBAROCEPHALA RÜBSAAMENI Czerny.

(Fig. 23).

Sobarocephala rübsaameni Czenny, Wien. ent. Ztg., vol. 23, p. 86, pl. 3, figs. 3-5 (1903).

Entire head reddish yellow, ocellar spot black, front shining, arista black and short-plumose, twice antennal length; head bristles reddish and strong, five long buccal hairs. Thorax shining reddish yellow, posterior part of mesonotum maculate with black, sometimes a smaller posthumeral blackish spot present, scutellum yellow, the tip sometimes black, pleurae yellowish, metathorax varying from black to yellow; prescutellar setae present, two pairs of lateral scutellar setae. Abdomen yellowish, with lateral blackish spots on second, fourth, fifth, and sixth segments. Legs yellowish, front tarsi somewhat dusky, flexor setae not developed on femora. Wings yellowish, pictured with brown markings, one forming a transversely oblique stripe between the ends of the first and anal veins, a second forming an oval spot at the end of the second vein, the third including the apex and following the last section of the fourth vein and the posterior crossvein, sometimes filling the second posterior cell; costal ratio $2.5: 1.3: 1$, fourth vein $1: 1: 1.5$, fifth vein $4: 1$; halteres and calypteres yellow. Length $5 \mathrm{~mm}$.

Distribution.-Five sepcimens collected by Pablo Schild in Costa Rica and by August Busck at the Trinidad River, Panama. The type specimen, on which Czerny erected the genus Sobarocephala, came from Peru. As preapical bristles are well developed on the specimens before us they were probably broken from the type.

77. SOBAROCEPHALA SETIPES, new species.

(Fig. 26.)

Male.-Front shining yellow, ocellar spot black, mouthparts and antennae yellow, arista black, plumose, cheeks not silvery, head bristles yellowish brown, three fine buccal hairs. Dorsum shining ochraceous, pleurae paler, sternal hairs not conspicuously abundant, prescutellars undeveloped, only one lateral seta on scutellum. Abdomen brown except at the yellowish base, sides and venter; hypopygium yellowish, small, the end valves round and minute. Legs yellowish, front tarsi dusky, anterior flexor bristles of front femora vestigial, about fourteen in posterior row, middle femora with two flexor rows of strong, close, outstanding bristles, about twenty in the posterior row and ten in the anterior. Wings yellowish hyaline, 
costal ratio $4: 1.2: 1$, fourth vein $1.1: 1: 3.2$, fifth vein $2: 1$; Halteres whitish. Length $3.5 \mathrm{~mm}$.

Holotype.-Marlboro, Md., collected by R. C. Shannon, 19 June, 1916; in National Museum, Cat. No. 26277, U.S.N.M.

78. SOBAROCEPHALA VALIDA, Williston.

(Fig. 30.)

Heteroneura valida, Williston, Trans. Ent. Soc. Lond., 1896, p. 388, fig. 136 (1896).-Czerny, Wien. ent. Ztg., vol. 22, p. 102 (1903).-Williston, Manual N. Amer. Dipt., 3 ed, p. 319 (1908).

Heteromeringia valida Malloch, Proc. Ent. Soc. Wash., vol. 20, p. 8 (1918).

Head including antennae, proboscis and occiput light yellow, arista black, pubescent, two and a half times length of antennae, bristles yellowish. Thorax light yellow, mesonotum broadly on the sides and behind and the scutellum brown or black, shining, metanotum yellow; the yellow of the front of the mesonotum extends as a broad central stripe to or beyond the suture. Abdomen black or dark brown, its base, the ovipositor and the small hypopygium yellow. Legs yellow, double rows of short setae on underside of anterior femora. Wings uniformly cinereous hyaline, narrow, the sections of costa $7: 1.5: 1$, of fourth vein $1: 1: 3.5$, of fifth vein $1.5: 1$. Length $2.5 \mathrm{~mm}$.

From cotype specimens from St. Vincent, from the collection of Cornell University.

\section{SOBAROCEPHALA VARIEGATA, new species.}

(Fig. 40.)

Male.-Head ochraceous, paler beneath, a small brownish spot under each eye; third antennal joint circular, luteous, a blackish spot at base of the black and bushy-plumose apical arista; head bristles reddish yellow, six fine hairs in buccal fringe, upper occipital orbits with a row of ten black stiff setae, postverticals very small, no ocellars. Thorax variegated black and yellow; mesonotum with three distinct pairs of black markings, including one pair of parallel vittae half the length of the mesonotum and extending to base of the black scutellum, one pair of oblique spots directly above the wings and fusing anteriorly with the first pair of stripes, and a third pair of narrow posthumeral fasciae, the last crossing the pleurae to the middle coxae; pleurae with two additional subalar spots and the hypopleurae black; presuturals undeveloped, two small lateral scutellar setae, mesonotal hairs black. Abdomen centrally black, first two segments yellow; hypopygium large and yellow, valves long, narrow, nearly parallel-sided. Legs yellow, the middle femora with brownish spot above knee, hind femora with central brownish 
ring, all tibiae slightly dusky due to the covering of stouter hairs; all femora with double row of short flexor setae, becoming stronger on apical half, tibial spurs black and not long. Wings hyaline, with an abrupt blackish clouding confined to the apical fourth, a variable pale spot in the cloud in middle of submarginal cell, a distinct clouding over posterior crossvein; sections of costa $4: 1.5: 1$, of fourth vein $1.5: 1: 2.5$, of fifth vein $2.3: 1$; halteres white. Length $5 \mathrm{~mm}$.

Types.-Six specimens, La Suiza de Turrialba, Costa Rica (Pablo Schild), Melander collection, one deposited in National Museum, Cat. No. 26278, U. S. N. M. The National Museum has a specimen from Corazal, Canal Zone, Panama, secured by August Busck.

80. SOBAROCEPHALA XANTHOMELANA, new species.

(Fig. 27.)

Front and occiput dark ochraceous, ocellar dot black, face and mouthparts yellow, cheeks silvery, facial margin shining yellow, antennae luteous, the third joint orbicular and with an apical blackish spot, arista short-plumose, black, three times antennal length; lateral bristles of head long, strong and black, five delicate buccal hairs. Mesonotum and scutellum black, a large yellow cordate central spot in front part of notum, metanotum blackish, the metapleurae black, pleurae otherwise pale yellow, no prescutellars. Abdomen black except whitish ovipositor or sometimes ferruginous hypopygium, valves oval and yellowish. Legs with all femora and coxae pale yellow, all tibiae and front tarsi blackish, apical and preapical bristles of middle tibiae strong, four strong setae on underside of front femora in posterior row toward knee. Wings narrow, uniformly infumated, costal ratio $5: 1: 1$, fourth vein $1: 1: 2.8$, fifth vein $2: 1$; halteres whitish. Length $3 \mathrm{~mm}$.

Types.-Four males and two females, Turrialba, Costa Rica, April to August, Pablo Schild, in Melander collection, and one male from same collector, in National Museum, Cat. No. 26279, U.S.N.M. The aberrent female with yellow dorsal triangle mentioned by Williston in his description of Heteroneura xanthops is very suggestive of the present species.

\section{BIBLIOGRAPHY.}

Indispensible to the student of this family because of its wealth of detailed information is the Revision der Heteroneuriden by $\mathrm{P}$. Leander Czerny, published in Wiener entomologische Zeitung, volume 22 , Heft 3, pages $61-107$ (1903). The papers that have appeared subsequent to this and to Aldrich's Catalogue of North American Diptera are as follows: 
Bezzi, M. Nomenklatorisches über Dipteren. Wien. ent. Ztg., vol. 26, pp. 51-56 (1907). Proposes Czernyola for Craspedochaeta.

Collin, J. E. Three new species of the "albimana" group of the genus Heteroneura. Ent. Mo. Mag., vol. 48, pp. 106-108 (1912).

Frey, R. Mitteilungen über südamerikanische Dipteren. Ofvers. finska Vet. Soc. Förhand., vol. 60, A. 14, pp. 1-35 (1918). Describes Sobarocephala finniläi.

Hendel, F. H. Sauter's Formosa-Ausbeute: Acalyptrate Musciden II. Suppl. Entom., vol. 2, pp. 77-112 (1913). Describes Phylloclusia.

Beiträge zur Kenntnis der acalyptraten Musciden. Deut. ent. Zts., 1917, pp. 33-47 (1917). Erects Alloclusia.

Johnson, C. W. A study of the Clusiodidae of the Eastern United States. Psyche, vol. 20, pp. 97-101 (1913).

Kertesz, K. Beiträge zur Kenntnis der Heteroneuriden. Ann. Mus. Hung., vol. 1, pp. 566-573 (1903). Gives key to genera.

Eine neue Gattung der Heteroneuriden. Ann. Mus. Hung., vol. 4, pp. 320-322 (1906). Describes Allometopon.

LAмв, C. G. Heteroneuridae, etc. of the Seychelles. Trans. Linn. Soc. Lond., vol. 16, pp. 307-372 (1914). Describes Allometopon flavum.

Malloch, J. R. A revision of the Dipterous Family Clusiodidae. Proc. Ent. Soc. Wash., vol. 2, pp. 2-8 (1918).

Notes on Clusiodidae. Occasional Papers Boston Soc. Nat. Hist., vol. 5, pp. 47-50 (1922).

Oldenberg, L. Vier neue paläarktische Akalypteren. Deut. ent. Zts., 1910, pp. 284-287 (1910). Describes Acartophthalmus bicolor. 


\section{EXPLANATION OF PLATES.}

\section{Plate 1.}

(All figures enlarged eight diameters; photogcaphed by A. L. Melander.)

FIg. 1. Clusia lateralis Loew.

2. Clusia occidentalis Malloch.

3. Clusia czernyi Johnson.

4. Clusiodes (Clusiaria) melanostoma Loew, form duplicata Malloch.

5. Clusiodes (Columbrella) johnsoni Malloch, form nigripalpis Malloch

6. Clusiodes (Clusiaria) nitida, new species.

7. Clusiodes albimana Meigen, form obscurior Loew.

8. Clusiodes (Clusiaria) terminalis, new species.

9. Clusiodes (Clusiaria) atra, new species.

\section{Plate 2.}

Frg. 10. Acartophthalmus nigrinus Zetterstedt.

11. Czernyola atra Kertesz, male.

12. Chaetoclusia longefilata, new species.

13. Czernyola fascipennis, new species.

14. Chaetoclusia xanthops Williston, cotype.

15. Chaetoclusia quadrivittata, new species.

16. Chaetoclusia bakeri Coquillett.

17. Heteromeringia nitida Johnson, form nigripes, new variety.

18. Heteromeringia flavipes Williston, cotype.

19. Heteromeringia fumipennis, new species.

20. Heteromeringia czernyi Kertesz.

21. Sobarocephala lachnosternum, new species and puparium.

Plate 3.

FIG. 22. Sobarocephala flava, new species.

23. Sobarocephala ruebsaameni Czerny.

24. Sobarocephala latipennis, new species.

25. Sobarocephala humeralis, new species.

26. Sobarocephala setipes, new species.

27. Sobarocephala xanthomelana, new species.

28. Sobaroce phala nigronotum, new species.

29. Sobarocephala fascipennis, new species.

30. Sobarocephala valida Williston, cotype.

31. Sobarocephala convergens Malloch.

Plate 4.

Fig. 32. Sobarocephala latifrons Loew.

33. Sobarocephala bistrigata Kertesz.

34. Sobarocephala annulata, new species.

35. Sobarocephala plumata, new species.

36. Sobarocephala bivittata, new species.

37. Sobarocephala lumbalis Williston, cotype.

38. Sobarocephala dorsata Czerny.

39. Sobarocephala plumatella, new species.

40. Sobarocephala variegata, new species.

41. Sobarocephala hypopygralis, new species.

42. Sobarocephala liturata, new species. 



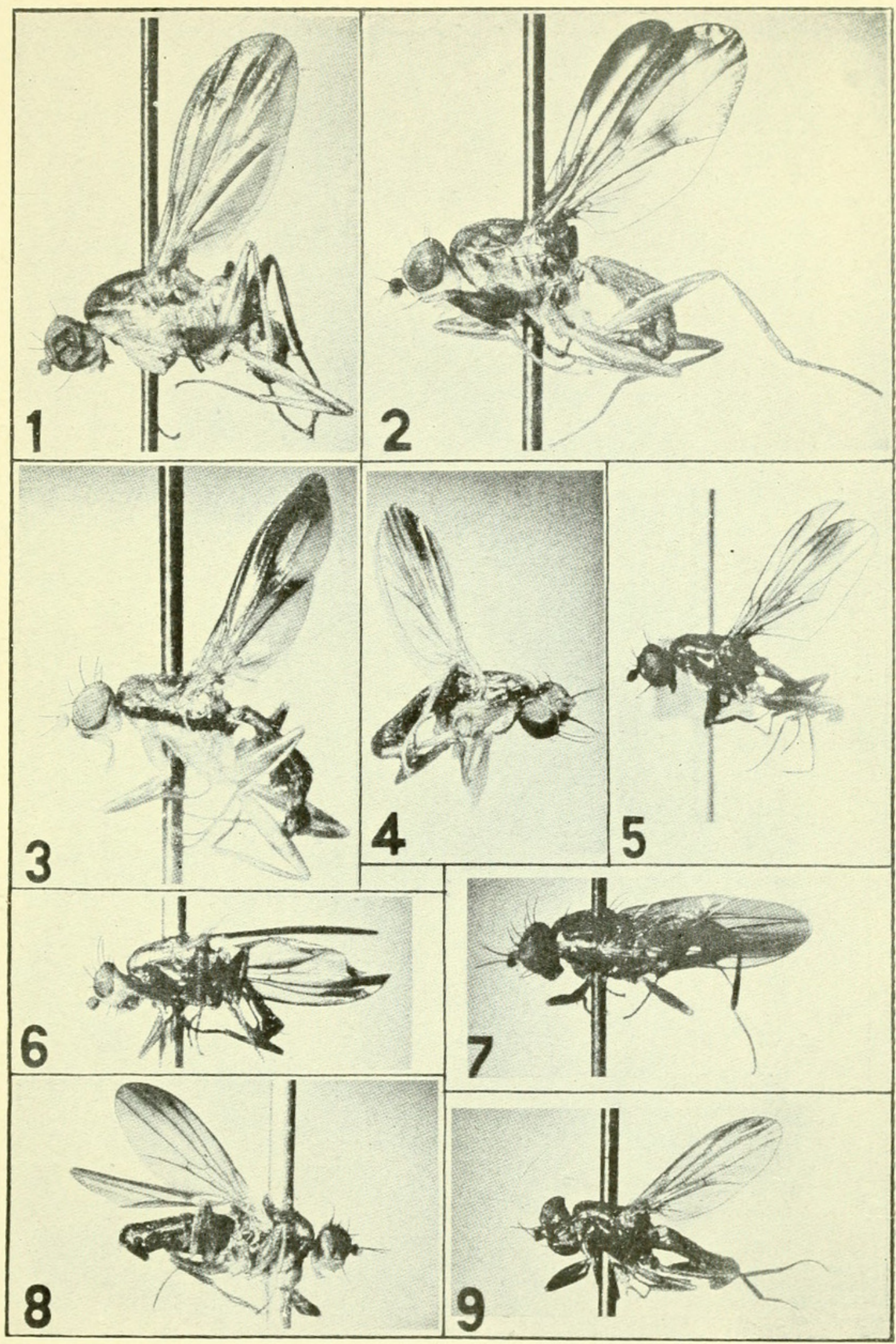

Flies of the family Clusildae.

FOR EXPLANATION OF PLATE SEE PAGE 51. 


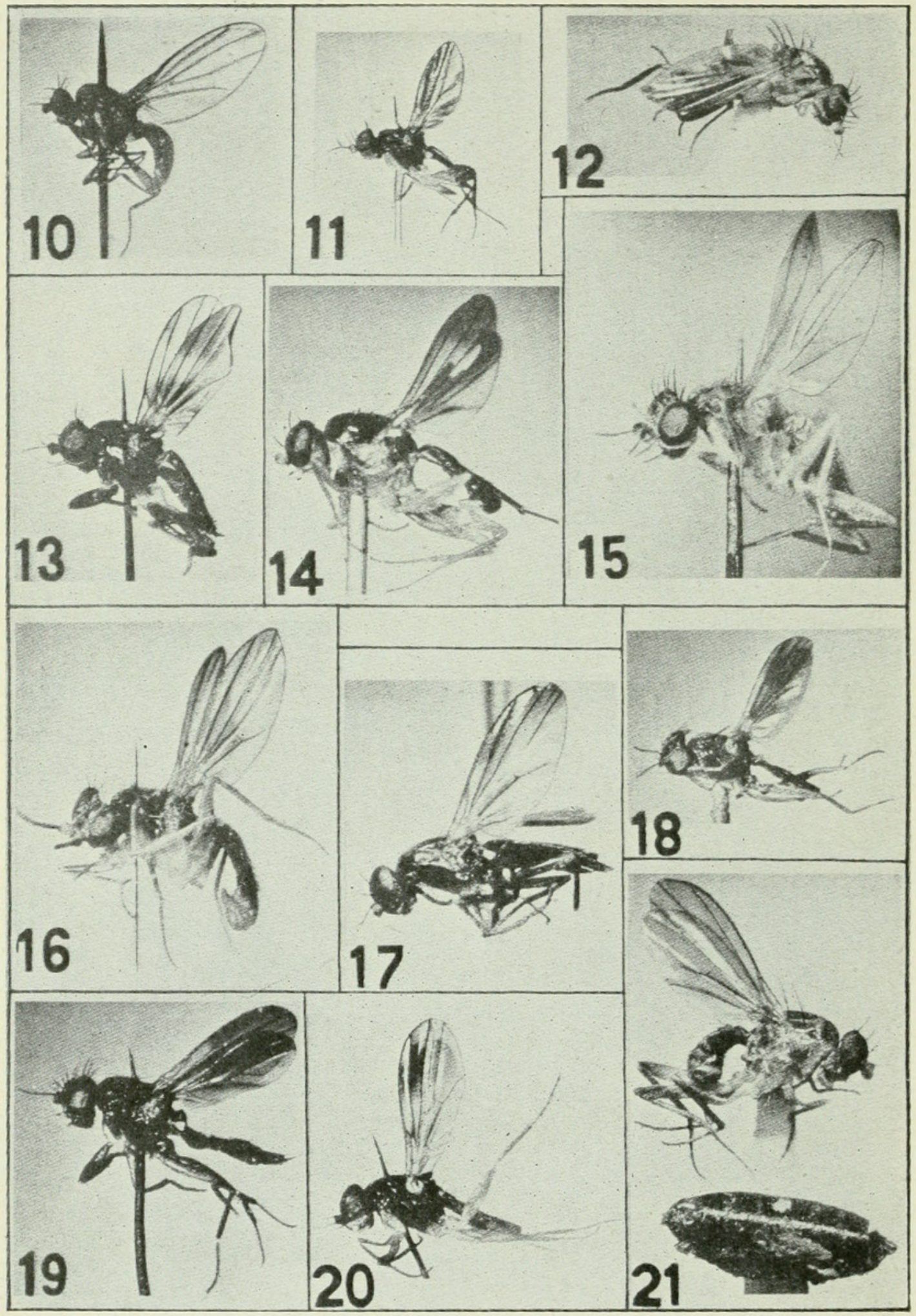

FLies of the FAMily ClusiIdaE. FOR EXPLANATION OF PLATE SEE PAGE 51 


\section{$2 \mathrm{BHL}$ Biodiversity Heritage Library}

Melander, A. L. and Argo, Naomi George. 1924. "Revision of the two-winged flies of the family Clusiidae." Proceedings of the United States National Museum 64(2501), 1-54. https://doi.org/10.5479/si.00963801.64-2501.1.

View This Item Online: https://www.biodiversitylibrary.org/item/32410

DOI: https://doi.org/10.5479/si.00963801.64-2501.1

Permalink: https://www.biodiversitylibrary.org/partpdf/1898

\section{Holding Institution}

Smithsonian Libraries

\section{Sponsored by}

Smithsonian

\section{Copyright \& Reuse}

Copyright Status: NOT_IN_COPYRIGHT

Rights: https://www.biodiversitylibrary.org/permissions/

This document was created from content at the Biodiversity Heritage Library, the world's largest open access digital library for biodiversity literature and archives. Visit BHL at https://www.biodiversitylibrary.org. 